\title{
HEDGING EFFECTIVENESS ASSESSMENT VIA VALUE-AT-RISK (VAR) AND CONDITIONAL VAR: AN EMPIRICAL INVESTIGATION FOR THE BRAZILIAN MANGO AND GRAPE EXPORTS
}

\begin{abstract}
The aim of this paper was to identify the hedge effectiveness of hypothetical future contracts for the Brazilian mango and grape exports via Value-at-Risk (VaR) and Conditional VaR hedging approaches. To this end, it was used two nonparametric models: the Historical Simulation and the Kernel Distribution. It was collected 300 monthly average mango and grape prices US\$ FOB/kg, between 1989 and 2013, from the site Comex Stat. As benchmarking model, it was also used the Minimum-Variance approach since it is widely employed by hedgers. The results showed that a variance reduction does not imply a VaR/CVaR reduction, and when it occurs, it does not happen in the same way. On the other hand, in general, the Minimum-CVaR via the Kernel method improve the reduction in portfolio's VaR, CVaR, and variance when compared with the Minimum-Variance approach, with a smaller optimal hedge ratio. For mango, the contract with maturity at five months had the largest CVaR reduction in the validation sample, while for grape, the largest $\mathrm{CVaR}$ reduction occurred with maturity at four months.
\end{abstract}

Abdinardo Moreira Barreto de Oliveira

Universidade Tecnológica Federal do Paraná

abdinardom@utfpr.edu.br

Joséte Florêncio dos Santos

Universidade Federal de Pernambuco

jfs@ufpe.br

Recebido em: 06/03/2018. Aprovado em: 06/11/2019.

Avaliado pelo sistema double blind review

Avaliador científico: Renato Silvério Campos

DOI: $10.21714 / 2238-68902018 v 20 n 2 p 134$

\section{RESUMO}

O objetivo deste artigo foi identificar a efetividade do hedge em contratos futuros hipotéticos para as exportações brasileiras de manga e uva via abordagens de hedging do Valor-em-Risco (VaR) e do VaR condicional. Para esse propósito, foram usados dois modelos não paramétricos: a Simulação Histórica e a Distribuição Kernel. Coletou-se 300 preços médios mensais US\$ FOB/kg de manga e uva entre 1989 e 2013 no site Comex Stat. Como modelo de comparação, também foi usada a abordagem da Variância Mínima, por causa de seu amplo uso pelos hedgers. Os resultados mostraram que uma redução na variância não implica numa redução no $\mathrm{VaR} / \mathrm{CVaR}$, e quando isso ocorre, não acontece da mesma maneira. Por outro lado, pode-se notar que, geralmente, o Mínimo-CVaR via método Kernel aumenta a redução do VaR, do CVaR e da variância, em vez da abordagem da Variância Mínima, com uma razão ótima de hedge menor. Para a manga, o contrato com vencimento em cinco meses foi o que teve a maior redução do CVaR na amostra de validação, enquanto que para a uva, a maior redução do CVaR ocorreu com o vencimento em quatro meses.

Keywords: Nonparametric models. Hedging, Exported fruits, Futures Markets.

Palavras-chave: Não-paramétricos, Hedging, Frutas exportadas, Mercados Futuros.

\section{INTRODUCTION}

In derivatives markets, the Minimum-Variance (JOHNSON, 1960; EDERINGTON, 1979; MYERS; THOMPSON, 1989; HULL, 2012) is the approach most known by the practitioners and scholars of hedging, which aim to mitigate the price risk of stocks, currencies or commodities through portfolios formed by their spot and futures prices. Its popularity is due to the facility of hedge ratio calculation, which involves variables well known from Statistic, organized in a variance-covariance matrix. Besides, it attends, under certain circumstances, the principle of maximization of the expected utility of the investor regardless of the chosen utility function (LIEN; TSE, 2002; ELTON et al., 2004).

However, some studies have questioned the use of variance-covariance matrix as the main measure of risk and hedging performance of portfolios (HARRIS; SHEN; 2006; HARRIS; SHEN; STOJA, 2010; CAO; HARRIS; SHEN, 2010; COTTER; HANLY, 2006, 2012; SAM, 2010). The first problem is concerned to symmetry: the variance-covariance matrix is a two-sided measure that puts the same weight to both positive and negative 
returns [eg.: Normal distribution], but the hedgers are concerned only with the probabilities distribution of negative returns.

The second problem is related to the moments that characterize the probability distribution of returns (SPANOS, 1999; CASELLA; BERGER, 2002; JORION, 2007). A Normal distribution can be entirely featured by its first and second moments: the mean [the location] and variance [the dispersion]. However, in case of nonnormality, the preferences of the investor fall on higher moments, such as skewness [the degree of asymmetry] and kurtosis [the degree of flatness], considering that the co-skewness and co-kurtosis of the assets returns are priced by the market. This happens because (1) negative skewness shows that the distribution has a long left tail and hence creates large negative values, and (2) a great kurtosis coefficient shows that the tails decrease more slowly than for the Normal distribution, implying a greater chance of large negative values.

A third problem related to the variancecovariance matrix in the Minimum-Variance approach is because its result does not measure the maximum loss or the expected loss that the portfolio could have beyond that maximum loss. In other words, minimizing the portfolio variance does not guarantee that its maximum loss (or minimum risk) is achieved; it is only possible if the third [skewness] and fourth [kurtosis] moments of probability distribution of returns were considered during the evaluation of the portfolio (HARRIS; SHEN; 2006; CAO; HARRIS; SHEN, 2010; COTTER; HANLY, 2006, 2012).

Due to these shortcomings presented by the Minimum-Variance approach, a set of alternative approaches have been developed to calculate the optimal hedge ratio that takes into account of the third and fourth moments of the probability distribution of returns.

Amongst them, the Value-at-Risk (VaR) and the Conditional Value-at-Risk ( $\mathrm{CVaR})$ have received a central importance to hedging operations in financial markets, regardless of calculating its static or dynamic optimal hedge ratio (BROOKS; HENRY; PERSAND, 2002; HARRIS; SHEN; 2006; CAO; HARRIS; SHEN, 2010; COTTER; HANLY, 2006, 2012; CHANG, 2011). In some of these studies, these approaches not only reduced the portfolio risk but also reduced its variance in levels similar to the Minimum-Variance approach.

Regarding the Brazilian exported fruits, especially mangoes and grapes, Oliveira and Santos $(2015,2017)$ showed by simulation that these fruits could use future contracts as a way to mitigate their price risk. However, these studies have employed the variance-covariance matrix as the main measure of risk and hedging performance of portfolios, in spite of the limitations aforementioned.

To broaden the discussion on hedging approaches for the Brazilian exported fruits, the aim of this paper is to identify the hedge effectiveness of futures contracts for mango and grape via VaR/CVaR hedging approaches. The specific objectives are: 1) To verify whether substantial reductions in portfolio variance obtained with hedging also offer large reductions in portfolio risk when that risk is measured by VaR/CVaR; 2) To verify whether a large reduction in the $\mathrm{VaR} / \mathrm{CVaR}$ portfolio can be obtained explicitly by minimizing the $\mathrm{VaR} / \mathrm{CVaR}$ instead the variance-covariance matrix.

Moreover, the use of agricultural prices would bring new information to the empirical evaluation of VaR/ CVaR to develop multiproduct hedge ratios, given that its performance, when applied to this context, might be quite different than those seen with financial asset prices (MANFREDO; LEUTHOLD, 1998).

These fruits were chosen because they were previously analyzed by Ferreira and Sampaio (2009) and Oliveira and Santos $(2015,2017)$ for their performance in a hypothetical futures market, as well as for being among the four main Brazilian exported fruits between 1997 and 2008 (BUENO; BACCARIN, 2012).

Regarding the in natura international mango market, Brazil is the $7^{\text {th }}$ producer and $4^{\text {th }}$ exporter. Approximately $95 \%$ of exportations come from the São Francisco valley (notably the cities of Petrolina, in Pernambuco state, and Juazeiro, in Bahia state). In 2012, the exportation reached 107 tons of mango valued in US\$ FOB 110 million, becoming the fruit that most generated exporting income to Brazil. Besides, it is worth noting that the revenues of mango exportation increased 257\% between 1995 and 2005 (LIMA; SILVA; SANTOS, 2013).

As for in natura grape, in 2013, the São Francisco valley exported 43 tons (99\% of total) to the Netherlands and to the United Kingdom, which are the two most important buyers (JULIÃO; BRANCO; LIMA, 2017).

In relation to the Gross Added Value (GAV) of the Brazilian agricultural industry, Petrolina reached, in 2012 , the $24^{\text {th }}$ place among the 100 most important cities in this sector, contributing with R\$ 436 million (BRASIL, 
2014b). In 2010, it reached the $2^{\text {nd }}$ place with a GAV of $\mathrm{R} \$ 620$ million (BRASIL, 2012). Concerning the value of production of agricultural goods, in 2016, Petrolina was among the 50 most important cities. As for the value of production of fruits, in the same year, Petrolina got the $1^{\text {st }}$ place and Juazeiro got the $7^{\text {th }}$ place among the 50 most important cities (BRASIL, 2016).

Since mango and grape have not yet have any commodity market for hedging, their exporters are exposed to price risk. For instance, during the 2008 financial crisis, the prices of exported mango and grape fell down considerably (between $-30 \%$ and $-67 \%$ ) because of two main factors: (1) strong depreciation of the dollar (US\$) against the Real (R\$) and (2) exported volume greater than the expected (MANDL; BARROS, 2009).

So far, the only use of VaR to gauge the price risk of fruits (without considering the hedging context) is found in Wang, Zhao and Huang (2010) for the Chinese fruit market, in which they employed several probability distribution functions and obtaining three groups of risk levels. In Brazil, some recent studies have used VaR/CVaR to measure the price risk in various agricultural commodities (ex. MOREIRA; SOUZA; DUCLÓS, 2014; CAPITANI; MATTOS, 2017; FELIPE; FRAILE, 2017, CASTRO; SILVA NETO, 2018); however, none of them employed the $\mathrm{VaR} / \mathrm{CVaR}$ as a hedge risk proxy for futures market.

Therefore, the economic meaning of this study gains relevance for stimulating the discussion among the stakeholders about the requisites needed to the development of futures contracts to new markets (particularly, in this study, the choice of models that better mitigate the price risk), as seen, for instance, in Capitani and Mattos (2015) for the rice produced in Brazil and Souza et al. (2015) for the rice produced in Mercosur.

In order to facilitate the understanding of the structure, this manuscript was organized as followws: in chapter 2 is presented some parametric and nonparametric models of VaR and CVaR; in chapter 3 is related previous studies linking VaR, CVaR and hedging; in chapter 4 is described the methodology; in chapter 5 are debated the results; and in chapter 6 , the conclusions and futures studies are pointed out.

\section{VAR/CVAR: PARAMETRIC AND NONPARAMETRIC MODELS}

The Value-at-Risk (VaR) is a measure that calculates the potential loss of an asset or portfolio, in a certain period of time and with a certain probability. From the viewpoint of an investor, VaR is the maximum loss associated with an extreme event, under normal market conditions. Thus, VaR catches the combined effect of underlying volatility [gauged by the moments of the observed probability distribution function] and exposure of these assets/portfolios to financial risks, becoming then an attractive measure due to its facility of understanding. Generally, VaR can be calculated through parametric and non-parametric estimations (JORION, 2007; HULL, 2012).

On the parametric estimates, the Normal distribution is the most employed probability distribution function to calculate VaR of assets/portfolios, because it needs only two parameters to be completely described: its mean and variance/standard deviation. Considering the returns of assets/ portfolios, VaR is calculated according to equation (1) ${ }^{1}$ :

$\operatorname{VaR}_{(\alpha)}=\int_{-\alpha}^{+\infty} f(x) d x=1-\int_{-\infty}^{-\alpha} f(x) d x=\mu-\epsilon * \sigma$

where $f(x)$ is the Normal distribution function, $\mu$ is the mean, $\alpha$ is the probability, $\in$ is the cumulative standard Normal distribution equivalent to $1-\alpha$ probability, and $\sigma$ is the standard deviation. If the distribution of returns is not close to Normal, other parametric distributions can be used $^{2}$, taking into account the probability intended and their shape-defining parameters (JORION, 2007).

As for the nonparametric estimates, the Historical Simulation is a popular way of estimating VaR, because it uses past data as a guidebook to what will happen in the future. It is also known as Empirical Probability Distribution (EPD) because it is free of shape-defining parameters.

The downside risk associated to VaR can be measured by the quantiles of data distribution, which are defined as VaR's cutoff values such that the area to their right (of left) represents a given probability $\alpha$, showed in equation $(2)^{3}$ :

$(1-\alpha)=\operatorname{prob}(x \geq \operatorname{VaR})=\int_{\operatorname{VaR}}^{+\infty} f(x) d x=1-\int_{-\infty}^{\operatorname{VaR}} f(x) d x=F^{-1}(\operatorname{VaR})(2)$

${ }^{1}$ The most common values for $\alpha$ are $95 \%$ and $99 \%$, which $\in$ are -1.645 and -2.326 , respectively. For returns, it is usually assume that $\mu=0$. For Normal distribution function, $f(x)=\frac{1}{\sqrt{2 \pi \sigma^{2}}} e^{\left.-\frac{1}{2}\left(\frac{x-\mu}{\sigma}\right)^{2}\right]}$ (JORION, 2007).

${ }^{2} \mathrm{~A}$ set of alternatives probability distribution functions is seen in Nadarajah, Chan and Afuecheta (2016).

${ }^{3}$ In computational ways, the VaR via nonparametric estimates can be easily calculated using Excel's PERCENTILE function, or QUANTILE function via $R$ free software, given a specific $\alpha$ (N.A). 
in which $\mathrm{F}($.$) is the cumulative distribution function (CDF)$ - the integral up to point VaR - and $\alpha$ is the probability desired (JORION, 2007).

Another possibility of using nonparametric estimates to VaR is through the Kernel method (GOURIEROUX; LAURENT; SCAILLET, 2000; SAM, 2010). This method employs the weighted average of the order statistics around the quantile of interest as the VaR estimate, in which the resulting estimation is distributionfree and consistent for independent or dependent returns series. $f(x)$ must be a smooth, positive, real-valued function that satisfies the following conditions: $\int f(x) d x=$ $1 ; \int x f(x) d x=0 ; \int x^{2} f(x) d x<\infty$. The nonparametric Kernel estimator for the VaR, calculated through the cumulative distribution function of the returns $[F(r)]$ either to assets or portfolios, is given by equation (3), which estimated VaR when solved numerically by the equation's root, for a given $\alpha$ probability:

$$
\begin{aligned}
& (1-\alpha)=\breve{F}(r) \therefore \frac{1}{T} \sum_{t=1}^{T} \mathrm{G}\left(\frac{\widehat{V a R}_{\alpha}-r_{t}}{b}\right)+\alpha-1=0 \\
& b=\sqrt[5]{\frac{4}{3 T}} \sigma
\end{aligned}
$$

in which $\mathrm{G}(.)^{4}$ is a cumulative distribution function, $T$ is the sample size, $r_{t}$ is the asset/portfolio's return in $t \in[1$, $\mathrm{T}]$ and $b$ is a bandwidth that controls the smoothness of the Kernel estimate, which can be calculated via equation (4), being $\sigma$ the standard deviation of the return of the asset/portfolio.

However, Artzner et al. (1999) proved that VaR is not a coherent measure of risk because it fails: (1) to satisfy the subadditivity axiom (i.e., the risk of the portfolio assets is never greater than the sum of the risk of the individual assets); (2) to recognize concentration of risks; (3) to encourage a reasonable allocations of risk among agents because it does not take into account the economic consequences of the events which it controls.

Instead, they suggested, through a set of proofs, a "tail conditional expectation" as a coherent measure of risk, also known now as Conditional VaR (CVaR) or

${ }^{4}$ Generally, $\mathrm{G}($.$) is the CDF of the standard Normal distribution because$ it is easy to integrate and differentiate from an analytical viewpoint, and to implement from a computerized viewpoint (GOURIEROUX; LAURENT; SCAILLET, 2000).
Expected Shortfall (ES) because it addresses all of the abovementioned VaR deficiencies. Moreover, as VaR is in general nonconvex, it may have several local minima, which is a problem for the optimization of the portfolio. The big advantage of the CVaR over VaR, as a risk measure, is that every local optimum is global, facilitating the optimization of the portfolio (PFLUG, 2000).

For calculating CVaR, a coherent risk measure is presented by equation (5) (ACERBI; TASCHE, 2002), for parametric and nonparametric calculations:

$$
\operatorname{CVaR}_{(\alpha)}(X)=-\frac{1}{1-\alpha} \int_{0}^{1-\alpha} \operatorname{VaR}_{(u)}(X) d u
$$

in which $\mathrm{X}$ is a real-valued random variable on a probability space $(\Omega, \alpha /, P)$ with $\mathrm{E}\left[\mathrm{X}^{-}\right]<\infty$ and $\alpha \in(0,1)$. It is worth noting that the smaller the level $(1-\alpha)$ the greater is the risk.

\section{PREVIOUS STUDIES REGARDING VAR, CVAR, AND HEDGING}

Harris and Shen (2006) employed historical simulation to calculate the optimal hedge ratio for 20 cross-hedged currency portfolios. Their results showed that the estimated Minimum-VaR hedge ratios are in general lesser than the equivalent Minimum-Variance hedge ratios, indicating that minimizing VaR typically implies taking a smaller short position.

In a later study, Cao, Harris, and Shen (2010) used a semi-parametric method for estimating minimum-VaR and minimum-CVaR hedge ratios for several indices, exchanges, and commodities, showing that this approach is superior to the standard minimum-variance and to the nonparametric approach (Historical Simulation) of Harris and Shen (2006).

Cotter and Hanly (2006) chose VaR (also via historical simulation) as one of the several alternatives hedging strategies ${ }^{5}$ instead of Minimum-Variance to calculate the effectiveness of optimal hedge ratios for stock index and stock index futures contracts from USA, Europe, and Asia equity markets. Posteriorly, Cotter and Hanly (2012) verified whether hedging effectiveness is affected by asymmetry in the return distribution via tailspecific metrics (LPM, VaR, and CVaR), applying static and dynamic hedging strategies for the S\&P500 index

${ }^{5} \mathrm{~A}$ set of alternatives hedging strategies is also detailed in Chen, Lee and Shrestha (2003). 
cash and futures to compare the hedging effectiveness of short and long hedgers.

For dynamics hedging, Brooks, Henry, and Persand (2002) showed that asymmetric multivariate GARCH models were able to capture the higher moments (skewness and kurtosis) of data distributions of the FTSE 100 stock index and stock index futures contract, reducing considerably portfolio risk.

In a similar way to broaden the discussion, Chang (2011) used a bivariate Markov regime switching autoregressive conditional heteroscedasticity (SWARCH) model to calculate the optimal hedge ratio via VaR strategy for the Taiwan Stock Exchange Capitalization Weighted Stock Index (TAIEX) futures data, getting better effectiveness results than the GARCH models.

\section{DATA AND METHODOLOGY}

\section{Data}

A survey was collected monthly from Comex Stat (former AliceWeb2) database (BRASIL, 2014a), belonging to Development, Industry and Foreign Trade Brazilian Ministry (MDIC) and according to codification (Table 1). It is notorious that the same product has more than one coding and more than one Comex Stat code. This happens because between 1989 and 1996 the coding system adopted by MDIC was the Brazilian Nomenclature of Goods (NBM); only from 1997 that the Mercosur Common Nomenclature (NCM) replaced the previous coding, remaining until today.

Moreover, it is also seen that with the same coding, mango had more than one Comex Stat code. This is because it had a sole code between 1989 and 1996, regardless of being fresh or dried; however, from Jan/1997, all the information about its exports were aggregate to the guavas and mangosteens, returning to have sole code only from Aug/2003.

For purposes of data formatting, all the cases shown in Table 1 were considered as if belonged to a sole time series by fruit. It was collected 300 observations of the following variables between Jan/1989 and Dec/2013: net weight $(\mathrm{kg})$ and exported value US\$ FOB (Freight on Board). With them, it calculated the average monthly price US\$ FOB $/ \mathrm{kg}$, that it is the main variable of this study (the smallest time scale in Comex Stat database is monthly). The sample size is based on studies by Oliveira and Santos $(2015,2017)$ in order to allow comparisons between previous and current results.

In case of missing values, they were filled by the arithmetic mean of adjacent values to preserve any seasonal effects existent in time series. Considering the 300 months involved, there were two consecutive missing data for mango and six missing data nonconsecutive for the grape. The average price time series were not deflated or inflated by any indexes.

Then it was made its descriptive statistic. After that, they were divided into two subsamples: the first (Jan/1989 to Dec/2008) was used for the estimation of the initial econometric and hedging models, with 240 observations, which tests and analysis were made on the subsequent sample (Jan/2009 to Dec/2013), for their validation, with 60 observations.

\section{Methodology}

To set up the futures prices, it was used the ARIMA models [see appendix A], applying a similar procedure performed by Oliveira and Santos (2015, 2017), via software EViews $8^{\circ}$ : (1) using the KPSS (1992) test to detect stationarity/unit root; (2) using the package ARIMASel to select the ARIMA coefficients by Bayesian Information Criterion (SCHWARZ, 1978); (3) using the Breusch-Godfrey LM test (BREUSCH, 1978; GODFREY, 1978) to detect serial correlation; (4) uing the Ljung-Box (1978) Q test to detect heteroscedasticity ${ }^{6}$. If

${ }^{6}$ It was also applied the Engle (1982) LM statistic test, with 10 lags, when $\mathrm{L}-\mathrm{B} \mathrm{Q}<5 \%$, to resolve any doubts about heteroskedasticity in variance. (OLIVEIRA; SANTOS, 2015, 2017).

TABLE 1 - Mango and grape coding according to Comex Stat

\begin{tabular}{cccc}
\hline Product & Type & Coding & Comex Stat Code \\
\hline \multirow{3}{*}{ Mango } & Fresh or dried & NBM & 0804500200 \\
& Guavas, mangoes and mangosteens, fresh and dried & NCM & 08045000 \\
& Fresh or dried & NCM & 08045020 \\
\cline { 2 - 4 } Grape & Fresh & NBM & 0806100000 \\
& Fresh & NCM & 08061000 \\
\hline
\end{tabular}

Source: Brasil (2014a)

Organizações Rurais \& Agroindustriais, Lavras, v. 20, n. 2, p. 134-154, 2018 
found, it was then applied the models GARCH to estimate the conditional volatility (BERA; HIGGINS, 1993); (5) using the Theil's $U_{1}$ test (BLIEMEL, 1973) to assess the forecast's accuracy. Lastly, the fitted values were set as the futures prices (BRESSAN, 2004).

Nextly, the price changes $\left(\Delta_{\mathrm{L}}\right)^{7}$ were computed for spot/futures prices by equation (6):

$\Delta_{(L)}=P_{(t)}-P_{(t-L)}$

in which $L \in[1,12]$ indicates the monthly maturity of the hypothetical futures contracts, on a rolling window ${ }^{8}$, which every month is traded a new futures contract. Thus, both fruits had 12 possible hedge scenarios for the Minimum-Variance, Minimum-VaR and Minimum-CVaR, with the aim to verify whether the optimal hedge ratio $(\mathrm{OHR})$ tends to naïve hedge as the increasing of maturity (CHEN; LEE; SHRESTHA, 2004).

The most effective choice was the one with the highest value obtained in the validation sample since it does not exceed the naïve hedge $(-1 \leq h \leq 1)$, either for short (negative values) or long (positive values) positions ${ }^{9}$ because it was not allowed any overdraft operations: the exporter could only trade exactly a number of fruits that had. It was not considered in the estimations transactions costs or brokerage.

To calculate the OHR $(h)$ and hedging effectiveness (HE) for the Minimum-Variance approach, both for estimation and validation subsamples, it was used the Johnson (1960) equations (7) and (8), in which $\sigma_{\mathrm{S}}$ and $\sigma_{\mathrm{F}}$ are, respectively, the standard deviation of $\Delta_{\mathrm{L}}$ for spot and futures prices, and $\rho$ is the correlation of spot and futures $\Delta_{\mathrm{L}}$ prices.

$$
\begin{aligned}
& h=-\frac{\operatorname{cov}_{S F}}{\sigma_{F}^{2}}=-\rho \frac{\sigma_{S}}{\sigma_{F}} \\
& H E=1-\left(\frac{\text { Variance }_{\text {hedged portfolio }}}{\text { Variance }_{\text {unhedged portfolio }}}\right)
\end{aligned}
$$

\footnotetext{
'The price change's equation for a portfolio is $\Delta \mathrm{p}_{(\mathrm{L})}=\Delta \mathrm{s}_{(\mathrm{L})}+\mathrm{h} \Delta \mathrm{f}_{(\mathrm{L})}, L \in[1,12]$. The choice for price changes, rather than price levels or price returns, is supported by Myers and Thompson (1989, p.862).

${ }^{8}$ For instance, for $L=3$, it means that every new contract has a maturity in 3 months. Therefore, a contract sold in January would mature in April, sold in February would mature in May, and so on. In every month, a new contract was sold, for every estimated matures (N.A).

${ }^{9}$ The price change's equation for a portfolio is $\Delta \mathrm{p}_{(\mathrm{L})}=\Delta \mathrm{s}_{(\mathrm{L})}+\mathrm{h} \Delta \mathrm{f}_{(\mathrm{L})}, L \in[1,12]$. The choice for price changes, rather than price levels or price returns, is supported by Myers and Thompson (1989, p.862).
}

To compute the OHR $(h)$ and hedging effectiveness (HE) for the Minimum-VaR approach by Historical Simulation, both for estimation and validation samples, the $\mathrm{R}$ ecdf and quantile functions were employed, combined with a monthly horizon $\mathrm{L} \in[1,12]$ and a $95 \%$ confidence level. To find out the value of $h$ that minimizes portfolio's $\mathrm{VaR}^{10}$, the $\mathrm{R}$ optimize function was used, ranging from -1 (naïve short position) to 1 (naïve long position). For the $H E$, it was employed the equation (9) (COTTER; HANLY, 2006):

$$
H E=1-\left(\frac{V a R_{95 \% \text { hedged portfolio }}}{\text { VaR }}\right)
$$

Lastly, for the Minimum-VaR and MinimumCVaR by the Kernel method, it was written an algorithm using the $\mathrm{R}$ software for this computation, which can be provided upon request. The uniroot function was used to estimate the VaR/CVaR that solves the equations (3) and (5), respectively, with $\alpha$ confidence level set to $95 \%$ and $h$ also ranging from -1 (naïve short position) to 1 (naïve long position). For the $H E$, equation (9) was used again.

Moreover, it was not used any switching hedging models in this study. This decision is supported by the results of Oliveira and Araújo (2018). Although there are some volatility clustering in the Brazilian mango and grape exports, the persistence in the variance of their returns is low, pointing to an absence of structural breaks in these time series.

\section{RESULTS}

\section{Descriptive statistics}

Table 2 shows the descriptive statistics for mango and grape spot prices (level US\$/kg FOB and log-return), between Jan/1989 and Dec/2013. For all series, the grape has the highest mean and standard deviation, while mango has the highest skewness and kurtosis.

All the series are asymmetric and leptokurtic, whose values contributed to reject the null hypothesis of data normality by the Jarque-Bera test. The stationary hypothesis was rejected for both level series but it was accepted for both log return series, given that the asymptotic values via KPSS test (with trend and intercept) were lower than the critical value.

${ }^{10}$ In practice, because of left tail of returns distribution has negative values, it seek for the maximum values. 
Regarding heteroscedasticity, the entire log-return series showed this phenomenon, given that the Engle (1982) LM test was higher than the critical value. Finally, both log return series has low persistence in variance, volatility clustering and no structural brakes, according to the methodology and the results of Oliveira and Araújo (2018).

Once the $\log$ return series is stationary, it was estimated the ARIMA/GARCH equations for $L \in[1$, 12], which indicates the lagging log return between $t$ and $t-L$. Nextly, the fitted values were calculated and set as the futures prices, as seen in Figures 1 and 2. A complete diagnosis of the ARIMA equations, with their coefficients, is shown in Appendix A.

\section{Price risk management for fruits via Minimum- Variance}

This section answers whether substantial reductions in portfolio variance obtained with hedging also offer large reductions in portfolio risk when that risk is measured by $\mathrm{VaR} / \mathrm{CVaR}$. Tables 3 and 4 show the results for the price risk of mango and grape, respectively, regarding optimal hedge ratio (h) and hedge effectiveness (risk measures reductions).

TABLE 2 - Summary statistics for mango and grape between Jan/1989-Dec/2013

\begin{tabular}{|c|c|c|c|c|}
\hline Variables & Level Mango & Level Grape & log Mango & log Grape \\
\hline Mean $(\mu)$ & 0.88 & 1.57 & 0.002 & 0.003 \\
\hline Maximum & 3.24 & 3.63 & 1.427 & 1.064 \\
\hline Minimum & 0.45 & 0.63 & -1.328 & -1.403 \\
\hline Standard Deviation $(\sigma)$ & 0.38 & 0.70 & 0.224 & 0.237 \\
\hline Skewness (S) & 2.67 & 1.08 & 0.689 & -0.069 \\
\hline Kurtosis $(\mathrm{K})$ & 13.90 & 3.30 & 15.708 & 9.754 \\
\hline Jarque-Bera test $\left[\chi^{2}, d f=2\right]^{*}$ & $1,842.06$ & 59.69 & $2,035.75$ & 568.57 \\
\hline KPSS LM asymptotic statistic ${ }^{* *}$ & 0.241 & 0.414 & 0.095 & 0.175 \\
\hline ARCH LM test $\left[\chi^{2}, d f=5\right]^{* * *}$ & N.A. & N.A. & 57.04 & 12.84 \\
\hline Observations $(\mathrm{N})$ & 300 & 300 & 299 & 299 \\
\hline
\end{tabular}

Note: * critical value at $5 \%: 5.99 ; * *$ critical value at $1 \%: 0.216 ; * * *$ critical value at $5 \%: 11.10$.

Source: Study data

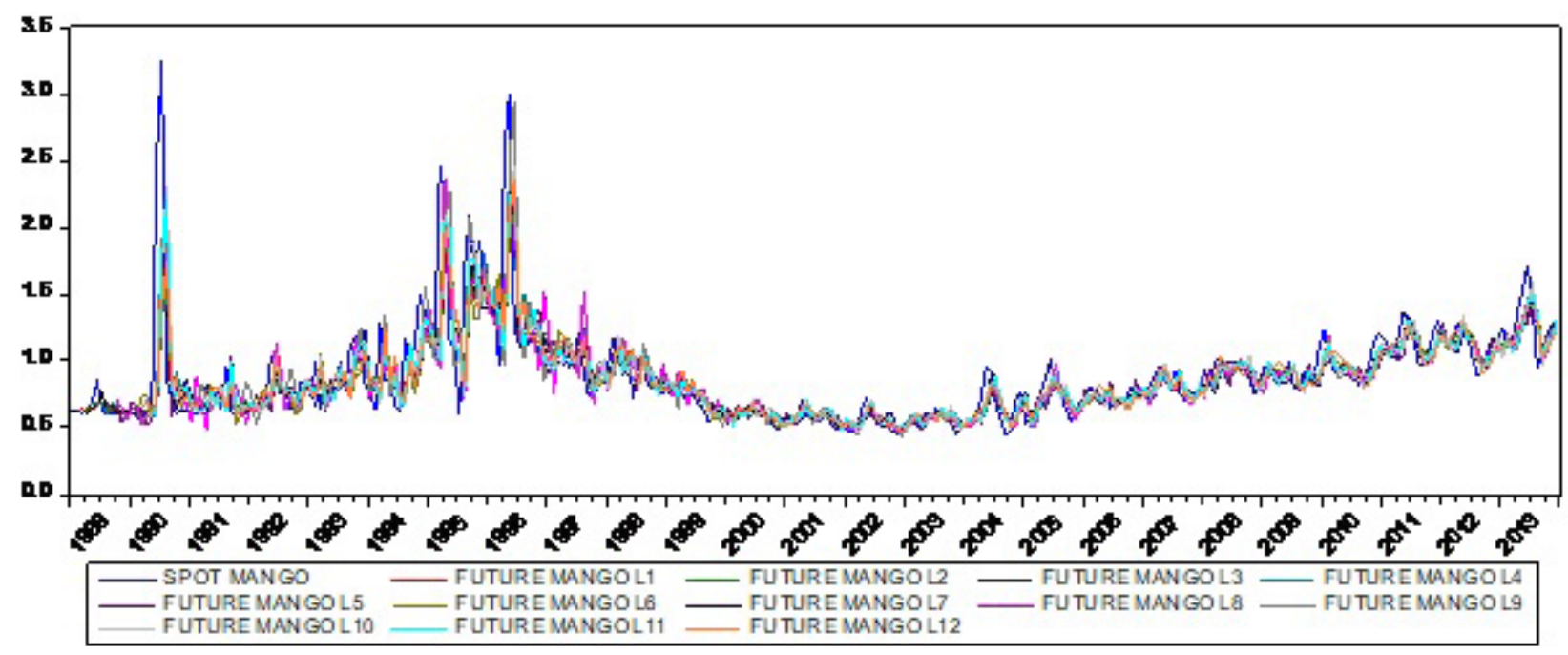

FIGURE 1 - Mango spot and futures prices (US\$/kg FOB) for 12 maturities

Source: Study data

Organizações Rurais \& Agroindustriais, Lavras, v. 20, n. 2, p. 134-154, 2018 


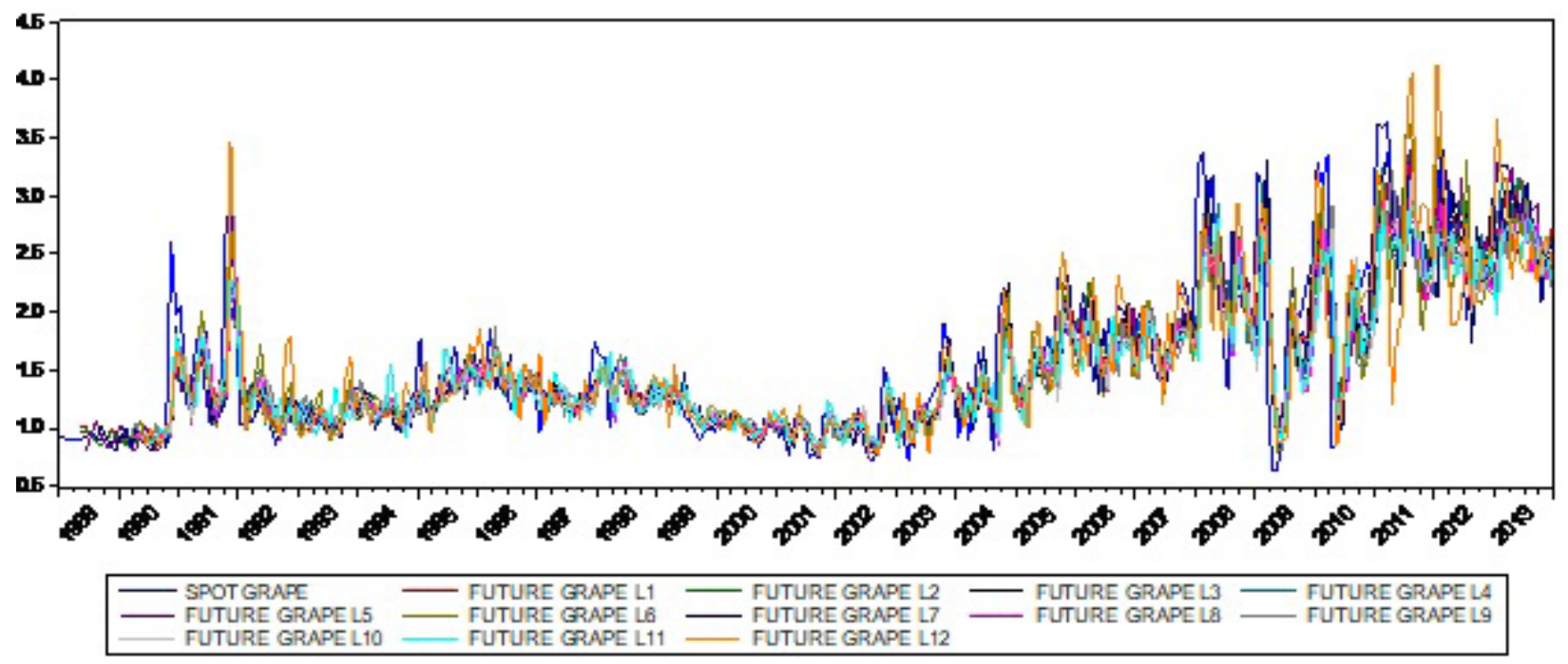

FIGURE 2 - Grape spot and futures prices (US\$ $/ \mathrm{kg}$ FOB) for 12 maturities Source: Study data

TABLE 3 - Hedging effectiveness of Minimum-Variance for mango

\begin{tabular}{|c|c|c|c|c|c|c|c|}
\hline \multirow{2}{*}{ Maturity } & \multirow{2}{*}{$\mathrm{h}$} & \multicolumn{3}{|c|}{$\begin{array}{c}\text { Estimation sample } \\
\text { (Jan/1989-Dec/2008) }\end{array}$} & \multicolumn{3}{|c|}{$\begin{array}{l}\text { Validation sample } \\
\text { (Jan/2009-Dec/2013) }\end{array}$} \\
\hline & & $\begin{array}{l}\text { Variance } \\
\text { reduction }\end{array}$ & $\mathrm{VaR}$ reduction & $\begin{array}{l}\mathrm{CVaR} \\
\text { reduction }\end{array}$ & $\begin{array}{l}\text { Variance } \\
\text { reduction }\end{array}$ & $\mathrm{VaR}$ reduction & $\begin{array}{l}\mathrm{CVaR} \\
\text { reduction }\end{array}$ \\
\hline 01 & 0.12 & $0.27 \%$ & $2.83 \%$ & $1.22 \%$ & $-1.60 \%$ & $3.58 \%$ & $-0.04 \%$ \\
\hline 02 & -0.30 & $1.85 \%$ & $-2.50 \%$ & $-2.02 \%$ & $7.69 \%$ & $8.06 \%$ & $5.05 \%$ \\
\hline 03 & -0.94 & $17.77 \%$ & $-8.60 \%$ & $8.10 \%$ & $23.34 \%$ & $-4.14 \%$ & $8.04 \%$ \\
\hline 04 & -0.73 & $11.89 \%$ & $-2.07 \%$ & $1.03 \%$ & $24.88 \%$ & $12.59 \%$ & $6.73 \%$ \\
\hline 05 & -0.97 & $27.61 \%$ & $-29.70 \%$ & $5.12 \%$ & $39.47 \%$ & $19.61 \%$ & $10.85 \%$ \\
\hline 06 & -0.74 & $22.28 \%$ & $-34.29 \%$ & $-4.05 \%$ & $26.37 \%$ & $-9.74 \%$ & $15.05 \%$ \\
\hline 07 & -0.63 & $18.84 \%$ & $-14.71 \%$ & $-3.66 \%$ & $35.55 \%$ & $9.33 \%$ & $-10.47 \%$ \\
\hline 08 & -0.67 & $21.84 \%$ & $9.88 \%$ & $5.26 \%$ & $31.90 \%$ & $-40.66 \%$ & $5.36 \%$ \\
\hline 09 & -0.64 & $22.32 \%$ & $1.66 \%$ & $3.52 \%$ & $36.17 \%$ & $-0.46 \%$ & $-8.86 \%$ \\
\hline 10 & -0.66 & $22.63 \%$ & $-4.50 \%$ & $2.18 \%$ & $35.98 \%$ & $-1.43 \%$ & $-9.86 \%$ \\
\hline 11 & -0.68 & $23.30 \%$ & $3.31 \%$ & $9.13 \%$ & $34.08 \%$ & $-22.40 \%$ & $-19.89 \%$ \\
\hline 12 & -0.74 & $18.64 \%$ & $5.69 \%$ & $4.58 \%$ & $35.54 \%$ & $10.58 \%$ & $-11.03 \%$ \\
\hline Average & -0.63 & $17.44 \%$ & $-6.08 \%$ & $2.53 \%$ & $27.45 \%$ & $-1.26 \%$ & $-0.76 \%$ \\
\hline
\end{tabular}

Note: For this table, it was used the Historical Simulation to calculate VaR and CVaR. Source: Study data

Regarding the $h$ values that minimize the variance of the portfolio, both fruits and samples do not tend to naive hedge as the maturity increases, rejecting the hypothesis of Chen, Lee and Shrestha (2004). Besides, the $h$ values were calculated from the estimation sample and employed to hedge the validation sample. In both samples, either to mango or grape, it is noticed that a variance reduction does not imply a $\mathrm{VaR} / \mathrm{CVaR}$ reduction, and when it occurs, it does not happen of the same way. 
TABLE 4 - Hedging effectiveness of Minimum-Variance for grape

\begin{tabular}{|c|c|c|c|c|c|c|c|}
\hline \multirow{2}{*}{ Maturity } & \multirow{2}{*}{$\mathrm{h}$} & \multicolumn{3}{|c|}{$\begin{array}{l}\text { Estimation sample } \\
(\mathrm{Jan} / 1989-\mathrm{Dec} / 2008)\end{array}$} & \multicolumn{3}{|c|}{$\begin{array}{c}\text { Validation sample } \\
\text { (Jan/2009-Dec/2013) }\end{array}$} \\
\hline & & $\begin{array}{l}\text { Variance } \\
\text { reduction }\end{array}$ & VaR reduction & $\begin{array}{c}\mathrm{CVaR} \\
\text { reduction }\end{array}$ & $\begin{array}{l}\text { Variance } \\
\text { reduction }\end{array}$ & VaR reduction & $\begin{array}{l}\mathrm{CVaR} \\
\text { reduction }\end{array}$ \\
\hline 01 & 0.12 & $0.51 \%$ & $1.58 \%$ & $1.33 \%$ & $-4.19 \%$ & $-0.70 \%$ & $-2.55 \%$ \\
\hline 02 & -0.70 & $18.63 \%$ & $-3.91 \%$ & $-1.68 \%$ & $33.69 \%$ & $19.67 \%$ & $17.83 \%$ \\
\hline 03 & -0.91 & $30.06 \%$ & $-1.25 \%$ & $8.72 \%$ & $40.10 \%$ & $46.97 \%$ & $21.01 \%$ \\
\hline 04 & -0.84 & $22.55 \%$ & $14.22 \%$ & $4.68 \%$ & $37.00 \%$ & $27.99 \%$ & $29.49 \%$ \\
\hline 05 & -0.70 & $12.78 \%$ & $-9.86 \%$ & $-2.68 \%$ & $28.60 \%$ & $7.31 \%$ & $12.20 \%$ \\
\hline 06 & -0.67 & $15.44 \%$ & $7.79 \%$ & $-2.78 \%$ & $24.53 \%$ & $11.64 \%$ & $-0.80 \%$ \\
\hline 07 & -0.82 & $26.01 \%$ & $17.48 \%$ & $9.07 \%$ & $30.08 \%$ & $21.07 \%$ & $-35.49 \%$ \\
\hline 08 & -0.73 & $20.85 \%$ & $14.65 \%$ & $5.20 \%$ & $31.36 \%$ & $-14.10 \%$ & $-9.42 \%$ \\
\hline 09 & -0.80 & $27.76 \%$ & $14.67 \%$ & $7.00 \%$ & $36.07 \%$ & $14.30 \%$ & $-7.95 \%$ \\
\hline 10 & -0.78 & $22.61 \%$ & $2.11 \%$ & $6.74 \%$ & $24.86 \%$ & $9.31 \%$ & $4.48 \%$ \\
\hline 11 & -0.75 & $22.96 \%$ & $-17.43 \%$ & $-3.02 \%$ & $16.04 \%$ & $0.52 \%$ & $11.07 \%$ \\
\hline 12 & -0.52 & $19.43 \%$ & $-36.28 \%$ & $-0.34 \%$ & $1.96 \%$ & $34.62 \%$ & $14.05 \%$ \\
\hline Average & -0.67 & $19.96 \%$ & $0.31 \%$ & $2.69 \%$ & $25.01 \%$ & $14.88 \%$ & $4.49 \%$ \\
\hline
\end{tabular}

Note: For this table, it was used the Historical Simulation to calculate VaR and CVaR

Source: Study data

According to Harris and Shen (2006), this happens because Minimum-Variance hedging can potentially increase left-skewness and kurtosis, making its effect on the portfolio risk uncertain. For mango, the average of skewness and kurtosis were -0.05 and 15.37 for unhedged portfolio, while for hedged portfolio the average of skewness and kurtosis were -0.25 and 12.51 , respectively. Similar effects happened to grape: its average of skewness and kurtosis were 0.24 and 4.15 for unhedged portfolio, whereas for hedged portfolio the average of skewness and kurtosis were -0.07 and 4.98 , in that order.

Thus, the main consequence of this is ambiguous, which compromises the decision-making of hedgers. For example, when observing maturity at five months for mango estimation sample, it has the highest variance reduction but also has the second worst VaR reduction and the fourth best $\mathrm{CVaR}$ reduction. However, when observing the validation sample, this maturity continues to have the largest variance reduction, but now also has the largest $\mathrm{VaR}$ reduction and the second best $\mathrm{CVaR}$ reduction. This fact occurs in a similar way for grape when observing maturity at three months.

To sum up this section, it was calculated the average variance, $\mathrm{VaR}$ and $\mathrm{CVaR}$ reduction, for both fruits and samples. It was found that for mango's estimation sample, its values were, respectively, $17.44 \%,-6.08 \%$, and $2.53 \%$, whereas, for validation sample, its values were $27.45 \%$, $-1.26 \%$, and $-0.76 \%$, in that order. For grape, it was found that for estimation sample, its average variance, VaR and CVaR reductions were, respectively $19.96 \%, 0.31 \%$, and $2.69 \%$, whereas, for validation sample, its values were, correspondingly, $25.01 \%, 14.88 \%$, and $4.49 \%$.

\section{Price risk management for fruits via Minimum-VaR and Minimum-CVaR: the Historical Simulation method}

This section answers whether a large reduction in the $\mathrm{VaR} / \mathrm{CVaR}$ of the portfolio can be obtained explicitly by minimizing the $\mathrm{VaR} / \mathrm{CVaR}$ instead of the variancecovariance matrix.

Tables 5 and 6 present the results for the price risk of mango and grape, respectively, regarding optimal hedge ratio (h) and hedge effectiveness by Minimum-VaR.

Regarding the values of $h$ that minimizes the VaR of the portfolio via Historical Simulation for both fruits and samples, they do not tend to naïve hedge as the maturity increases, rejecting again the hypothesis of Chen, Lee and Shrestha (2004). Besides, the $h$ values calculated for the Minimum-VaR are smaller than those calculated for the Minimum-Variance, verifying the same phenomena 
TABLE 5 - Hedging effectiveness of Minimum-VaR (Historical Simulation) for mango

\begin{tabular}{cccccccc}
\hline & & \multicolumn{3}{c}{$\begin{array}{c}\text { Estimation sample } \\
\text { Maturity }\end{array}$} & $\mathrm{h}$ & \multicolumn{2}{c}{$\begin{array}{c}\text { Validation sample } \\
\text { (Jan/2009-Dec/2013) }\end{array}$} \\
\cline { 2 - 9 } & & $\begin{array}{c}\text { Variance } \\
\text { reduction }\end{array}$ & VaR reduction & $\begin{array}{c}\text { CVaR } \\
\text { reduction }\end{array}$ & $\begin{array}{c}\text { Variance } \\
\text { reduction }\end{array}$ & VaR reduction & $\begin{array}{c}\text { CVaR } \\
\text { reduction }\end{array}$ \\
\hline 01 & 0.53 & $-2.94 \%$ & $10.93 \%$ & $0.22 \%$ & $-12.38 \%$ & $1.25 \%$ & $-0.20 \%$ \\
02 & -0.34 & $1.82 \%$ & $2.28 \%$ & $-2.47 \%$ & $8.33 \%$ & $9.31 \%$ & $5.08 \%$ \\
03 & -0.75 & $17.08 \%$ & $2.15 \%$ & $7.61 \%$ & $22.39 \%$ & $-0.59 \%$ & $6.46 \%$ \\
04 & -0.15 & $4.43 \%$ & $7.71 \%$ & $1.30 \%$ & $7.47 \%$ & $-2.05 \%$ & $2.72 \%$ \\
05 & 0.01 & $-0.77 \%$ & $0.37 \%$ & $-0.30 \%$ & $-0.95 \%$ & $-0.29 \%$ & $-0.38 \%$ \\
06 & -0.00 & $0.01 \%$ & $0.00 \%$ & $0.00 \%$ & $0.01 \%$ & $0.00 \%$ & $0.00 \%$ \\
07 & -0.40 & $16.20 \%$ & $4.72 \%$ & $0.60 \%$ & $26.90 \%$ & $7.30 \%$ & $-6.55 \%$ \\
08 & -0.67 & $21.84 \%$ & $9.89 \%$ & $5.27 \%$ & $31.89 \%$ & $-40.60 \%$ & $5.39 \%$ \\
09 & -0.23 & $13.02 \%$ & $13.66 \%$ & $4.14 \%$ & $18.22 \%$ & $-11.84 \%$ & $4.41 \%$ \\
10 & -0.38 & $18.44 \%$ & $9.61 \%$ & $4.58 \%$ & $27.01 \%$ & $-6.28 \%$ & $3.64 \%$ \\
11 & -0.36 & $18.06 \%$ & $21.04 \%$ & $6.85 \%$ & $24.81 \%$ & $2.77 \%$ & $10.46 \%$ \\
12 & -0.50 & $16.73 \%$ & $16.78 \%$ & $6.59 \%$ & $29.22 \%$ & $16.38 \%$ & $-7.38 \%$ \\
\hline Average & -0.27 & $10.33 \%$ & $8.26 \%$ & $2.86 \%$ & $15.25 \%$ & $-2.05 \%$ & $1.97 \%$ \\
\hline
\end{tabular}

Source: Study data

TABLE 6 - Hedging effectiveness of Minimum-VaR (Historical Simulation) for grape

\begin{tabular}{|c|c|c|c|c|c|c|c|}
\hline \multirow{2}{*}{ Maturity } & \multirow{2}{*}{$\mathrm{h}$} & \multicolumn{3}{|c|}{$\begin{array}{l}\text { Estimation sample } \\
\text { (Jan/1989-Dec/2008) }\end{array}$} & \multicolumn{3}{|c|}{$\begin{array}{c}\text { Validation sample } \\
\text { (Jan/2009-Dec/2013) }\end{array}$} \\
\hline & & $\begin{array}{l}\text { Variance } \\
\text { reduction }\end{array}$ & VaR reduction & $\begin{array}{c}\mathrm{CVaR} \\
\text { reduction }\end{array}$ & $\begin{array}{l}\text { Variance } \\
\text { reduction }\end{array}$ & VaR reduction & $\begin{array}{l}\mathrm{CVaR} \\
\text { reduction }\end{array}$ \\
\hline 01 & 0.14 & $0.49 \%$ & $1.81 \%$ & $1.41 \%$ & $-5.12 \%$ & $-0.52 \%$ & $-3.21 \%$ \\
\hline 02 & -0.34 & $13.63 \%$ & $3.15 \%$ & $4.45 \%$ & $23.14 \%$ & $-4.77 \%$ & $12.49 \%$ \\
\hline 03 & -0.35 & $18.67 \%$ & $7.99 \%$ & $5.84 \%$ & $24.84 \%$ & $23.52 \%$ & $11.27 \%$ \\
\hline 04 & -0.46 & $17.82 \%$ & $18.70 \%$ & $3.59 \%$ & $28.30 \%$ & $30.91 \%$ & $20.29 \%$ \\
\hline 05 & 0.49 & $-24.25 \%$ & $4.07 \%$ & $-1.84 \%$ & $-39.17 \%$ & $-19.38 \%$ & $-21.08 \%$ \\
\hline 06 & -0.24 & $8.99 \%$ & $18.96 \%$ & $0.79 \%$ & $12.07 \%$ & $4.56 \%$ & $3.74 \%$ \\
\hline 07 & -0.87 & $25.88 \%$ & $18.59 \%$ & $8.30 \%$ & $29.90 \%$ & $20.59 \%$ & $-39.38 \%$ \\
\hline 08 & -0.52 & $19.16 \%$ & $18.39 \%$ & $6.10 \%$ & $27.31 \%$ & $-8.87 \%$ & $-5.35 \%$ \\
\hline 09 & -0.44 & $22.24 \%$ & $15.88 \%$ & $8.45 \%$ & $27.42 \%$ & $12.02 \%$ & $-2.29 \%$ \\
\hline 10 & -0.34 & $15.57 \%$ & $14.39 \%$ & $4.99 \%$ & $17.72 \%$ & $9.38 \%$ & $8.30 \%$ \\
\hline 11 & 0.43 & $-34.01 \%$ & $9.71 \%$ & $-9.10 \%$ & $-32.32 \%$ & $-11.23 \%$ & $-18.95 \%$ \\
\hline 12 & 0.05 & $-3.87 \%$ & $1.57 \%$ & $-1.24 \%$ & $-2.56 \%$ & $-3.51 \%$ & $-1.90 \%$ \\
\hline Average & -0.20 & $6.69 \%$ & $11.10 \%$ & $2.64 \%$ & $9.29 \%$ & $4.39 \%$ & $-3.00 \%$ \\
\hline
\end{tabular}

Source: Study data 
previously seen in Harris and Shen (2006). Somehow, it is noticed that the minimization of $\mathrm{VaR}$ by Historical Simulation does imply a reduction in variance and CVaR a similar way, in contrast with the Minimum-Variance results.

Regarding mango's estimation sample, the average reduction of variance, $\mathrm{VaR}$, and CVaR were, respectively, $10.33 \%, 8.26 \%$, and $2.86 \%$ whereas, for validation sample, its values were $15.25 \%,-2.05 \%$, and $1.97 \%$. For grape's estimation sample, its average reduction of variance, VaR, and CVaR were, respectively $6.69 \%, 11.10 \%$, and $2.64 \%$, whereas, for validation sample, its values were, correspondingly, $9.29 \%, 4.39 \%$, and $-3.00 \%$.

Tables 7 and 8 present the results for the price risk of mango and grape, respectively, regarding optimal hedge ratio (h) and hedge effectiveness by Minimum-CVaR.

Similar to the results for the Minimum-VaR, the values of $h$ that minimizes the CVaR of the portfolio via Historical Simulation do not tend to naive hedge as the maturity increases, for both fruits and samples, rejecting again the hypothesis of Chen, Lee and Shrestha (2004).

Nevertheless, the values of $h$ calculated for the Minimum-CVaR are higher than those calculated for the Minimum-VaR but still lower than those calculated for the Minimum-Variance. In addition, for both estimation and validation samples, the reduction in variance by Minimum-CVaR is greater than that obtained by Minimum-VaR.

Concerning mango's estimation sample, the average reduction of variance, $\mathrm{VaR}$, and $\mathrm{CVaR}$ were, respectively, $14.21 \%, 0.90 \%$, and $4.53 \%$ whereas, for validation sample, its values were $20.27 \%,-0.97 \%$, and $-0.13 \%$. For grape's estimation sample, its average reduction of variance, VaR, and CVaR were, respectively, $16.12 \%, 3.33 \%$, and $4.99 \%$, whereas, for validation sample, its values were, correspondingly, $19.03 \%, 11.19 \%$, and $4.50 \%$.

However, calculating VaR/CVaR by Historical Simulation has a disadvantage: this method does not represent all the possibilities that might occur for the data. In other words, the Empirical Probability Distribution (EPD) is just a subset of infinite possibilities of its Theoretical Probability Distribution (TPD). Thus, the hedge ratio, the VaR/CVaR results and the hedge effectiveness should be specified incorrectly. To recalculate the Minimum-VaR and Minimum-CVaR and correct this failure, the Kernel method was used.

Price risk management for fruits via Minimum-VaR and Minimum-CVaR: the Kernel method.

TABLE 7 - Hedging effectiveness of Minimum-CVaR (Historical Simulation) for mango

\begin{tabular}{|c|c|c|c|c|c|c|c|}
\hline \multirow{2}{*}{ Maturity } & \multirow{2}{*}{$\mathrm{h}$} & \multicolumn{3}{|c|}{$\begin{array}{c}\text { Estimation sample } \\
\text { (Jan/1989-Dec/2008) }\end{array}$} & \multicolumn{3}{|c|}{$\begin{array}{c}\text { Validation sample } \\
\text { (Jan/2009-Dec/2013) }\end{array}$} \\
\hline & & $\begin{array}{l}\text { Variance } \\
\text { reduction }\end{array}$ & VaR reduction & $\begin{array}{c}\mathrm{CVaR} \\
\text { reduction }\end{array}$ & $\begin{array}{l}\text { Variance } \\
\text { reduction }\end{array}$ & VaR reduction & $\begin{array}{c}\mathrm{CVaR} \\
\text { reduction }\end{array}$ \\
\hline 01 & 0.29 & $-0.27 \%$ & $-3.70 \%$ & $2.67 \%$ & $-5.03 \%$ & $8.65 \%$ & $-0.11 \%$ \\
\hline 02 & 0.15 & $-2.31 \%$ & $-3.40 \%$ & $0.95 \%$ & $-5.76 \%$ & $-1.89 \%$ & $-4.84 \%$ \\
\hline 03 & -0.95 & $17.77 \%$ & $-9.50 \%$ & $8.10 \%$ & $23.34 \%$ & $-4.41 \%$ & $8.18 \%$ \\
\hline 04 & -0.29 & $7.55 \%$ & $3.74 \%$ & $2.26 \%$ & $13.18 \%$ & $-0.56 \%$ & $4.21 \%$ \\
\hline 05 & -0.70 & $25.42 \%$ & $-13.12 \%$ & $6.86 \%$ & $34.14 \%$ & $14.01 \%$ & $11.44 \%$ \\
\hline 06 & -0.26 & $12.80 \%$ & $-7.31 \%$ & $0.68 \%$ & $16.47 \%$ & $9.67 \%$ & $6.68 \%$ \\
\hline 07 & -0.24 & $11.61 \%$ & $3.13 \%$ & $0.90 \%$ & $18.21 \%$ & $5.97 \%$ & $-3.98 \%$ \\
\hline 08 & -0.42 & $18.67 \%$ & $6.78 \%$ & $6.37 \%$ & $26.20 \%$ & $-27.29 \%$ & $7.97 \%$ \\
\hline 09 & -0.48 & $20.95 \%$ & $2.89 \%$ & $5.10 \%$ & $31.60 \%$ & $-3.27 \%$ & $-0.20 \%$ \\
\hline 10 & -0.38 & $18.44 \%$ & $9.59 \%$ & $4.58 \%$ & $27.02 \%$ & $-6.29 \%$ & $3.64 \%$ \\
\hline 11 & -0.74 & $23.14 \%$ & $5.15 \%$ & $9.22 \%$ & $34.43 \%$ & $-22,72 \%$ & $-27.08 \%$ \\
\hline 12 & -0.50 & $16.80 \%$ & $16.49 \%$ & $6.62 \%$ & $29.39 \%$ & $16.44 \%$ & $-7.45 \%$ \\
\hline Average & -0.38 & $14.21 \%$ & $0.90 \%$ & $4.53 \%$ & $20.27 \%$ & $-0.97 \%$ & $-0.13 \%$ \\
\hline
\end{tabular}

Source: Study data 
TABLE 8 - Hedging effectiveness of Minimum-CVaR (Historical Simulation) for grape

\begin{tabular}{|c|c|c|c|c|c|c|c|}
\hline \multirow{2}{*}{ Maturity } & \multirow{2}{*}{$\mathrm{h}$} & \multicolumn{3}{|c|}{$\begin{array}{c}\text { Estimation sample } \\
(\mathrm{Jan} / 1989-\mathrm{Dec} / 2008)\end{array}$} & \multicolumn{3}{|c|}{$\begin{array}{c}\text { Validation sample } \\
\text { (Jan/2009-Dec/2013) }\end{array}$} \\
\hline & & $\begin{array}{l}\text { Variance } \\
\text { reduction }\end{array}$ & VaR reduction & $\begin{array}{c}\mathrm{CVaR} \\
\text { reduction }\end{array}$ & $\begin{array}{l}\text { Variance } \\
\text { reduction }\end{array}$ & VaR reduction & $\begin{array}{c}\mathrm{CVaR} \\
\text { reduction }\end{array}$ \\
\hline 01 & 0.18 & $0.38 \%$ & $0.70 \%$ & $1.53 \%$ & $-6.84 \%$ & $-0.20 \%$ & $-4.35 \%$ \\
\hline 02 & -0.23 & $10.20 \%$ & $-0.41 \%$ & $4.93 \%$ & $17.12 \%$ & $-8.76 \%$ & $10.02 \%$ \\
\hline 03 & -0.74 & $29.03 \%$ & $1.97 \%$ & $8.76 \%$ & $38.68 \%$ & $41.31 \%$ & $21.30 \%$ \\
\hline 04 & -0.72 & $22.07 \%$ & $15.48 \%$ & $4.68 \%$ & $35.75 \%$ & $29.07 \%$ & $28.06 \%$ \\
\hline 05 & -0.05 & $1.85 \%$ & $-0.30 \%$ & $0.13 \%$ & $3.26 \%$ & $-3.13 \%$ & $2.26 \%$ \\
\hline 06 & -0.16 & $6.50 \%$ & $14.12 \%$ & $0.90 \%$ & $8.56 \%$ & $3.14 \%$ & $3.56 \%$ \\
\hline 07 & -0.61 & $24.31 \%$ & $8.84 \%$ & $10.90 \%$ & $28.19 \%$ & $22.86 \%$ & $-21.18 \%$ \\
\hline 08 & -0.56 & $19.66 \%$ & $17.25 \%$ & $6.21 \%$ & $28.21 \%$ & $-9.70 \%$ & $-6.00 \%$ \\
\hline 09 & -0.57 & $25.44 \%$ & $14.55 \%$ & $8.77 \%$ & $31.82 \%$ & $14.10 \%$ & $-4.28 \%$ \\
\hline 10 & -0.82 & $22.54 \%$ & $0.30 \%$ & $6.76 \%$ & $24.65 \%$ & $8.42 \%$ & $3.36 \%$ \\
\hline 11 & -0.30 & $14.55 \%$ & $-0.91 \%$ & $1.67 \%$ & $12.42 \%$ & $4.38 \%$ & $10.40 \%$ \\
\hline 12 & -0.33 & $16.91 \%$ & $-31.64 \%$ & $4.59 \%$ & $6.51 \%$ & $32.81 \%$ & $10.84 \%$ \\
\hline Average & -0.41 & $16.12 \%$ & $3.33 \%$ & $4.99 \%$ & $19.03 \%$ & $11.19 \%$ & $4.50 \%$ \\
\hline
\end{tabular}

Source: Study data

This section answers whether a large reduction in the $\mathrm{VaR} / \mathrm{CVaR}$ of the portfolio can be obtained explicitly by minimizing the VaR/CVaR by the Kernel method.

Unlike to the results for the minimum VaR and CVaR via Historical Simulation, the values of $h$ that minimize the VaR and CVaR portfolios via the Kernel method do not tend to naïve hedge as the maturity increases, for both fruits and samples, rejecting again the hypothesis of Chen, Lee and Shrestha (2004). Moreover, the values of $h$ calculated by Kernel method are similar to those calculated for the Historical Simulation but still lower than those calculated for the Minimum-Variance.

Regarding the average reduction of variance by Minimum-VaR, the Kernel method had better values than Historical Simulation, for both fruits and both samples. For mango's estimation and validation samples, the average variance reduction was $12.25 \%$ and $17.92 \%$, while for the grape, the average variance reduction of estimation and validation samples were $16.19 \%$ and $19.70 \%$, as presented in Tables 9 and 10.

Regarding the average reduction of VaR, although the Kernel method presented lower results than Historical Simulation on estimation samples for both fruits, it presented better results on validation samples, as a consequence of the variability of their values through time, suggesting that $h$ can be dynamic instead of static. For mango's estimation and validation samples, the average reduction of $\mathrm{VaR}$ was $5.56 \%$ and $4.42 \%$, while for grape, and the average reduction for estimation and validation samples were $6.61 \%$ and $9.86 \%$, respectively.

Additionally, the Minimum-VaR via the Kernel method offers a better average reduction in $\mathrm{CVaR}$ than the Historical Simulation. For both estimation and validation samples, the values for mango were $3.76 \%$ and $4.76 \%$, while the values for grape were $4.47 \%$ and $8.44 \%$, respectively.

Next, tables 11 and 12 show, respectively, the results for the price risk of mango and grape, regarding optimal hedge ratio (h) and hedge effectiveness by Minimum-CVaR.

Similar to what happened with the Minimum-VaR, the Minimum-CVaR by the Kernel method had a better reduction in the validation samples than the Historical simulation for both fruits. The exception was mango, which also had a better reduction in the estimation sample. Regarding the average reduction of variance by Minimum$\mathrm{CVaR}$, the Kernel method presented better values than Historical Simulation (VaR and CVaR) and Minimum-VaR by Kernel method for both fruits and samples. 
TABLE 9 - Hedging effectiveness of Minimum-VaR (Kernel method) for mango

\begin{tabular}{cccccccc}
\hline \multirow{2}{*}{ Maturity } & $\mathrm{h}$ & \multicolumn{2}{c}{ Estimation sample (Jan/1989-Dec/2008) } & \multicolumn{2}{c}{ Validation sample (Jan/2009-Dec/2013) } \\
\cline { 3 - 8 } & & Variance reduction & VaR reduction & CVaR reduction & Variance reduction & VaR reduction & CVaR reduction \\
\hline 01 & 0.20 & $0.14 \%$ & $1.96 \%$ & $1.03 \%$ & $-3.08 \%$ & $2.09 \%$ & $-0.31 \%$ \\
02 & -0.26 & $1.82 \%$ & $1.89 \%$ & $-2.36 \%$ & $7.02 \%$ & $7.29 \%$ & $4.14 \%$ \\
03 & -0.53 & $14.42 \%$ & $4.29 \%$ & $5.77 \%$ & $18.86 \%$ & $7.54 \%$ & $6.88 \%$ \\
04 & -0.24 & $6.50 \%$ & $3.46 \%$ & $1.87 \%$ & $11.19 \%$ & $3.41 \%$ & $4.13 \%$ \\
05 & -0.21 & $10.64 \%$ & $1.85 \%$ & $4.07 \%$ & $13.36 \%$ & $5.17 \%$ & $5.63 \%$ \\
06 & -0.19 & $10.01 \%$ & $2.38 \%$ & $3.37 \%$ & $12.97 \%$ & $3.85 \%$ & $5.81 \%$ \\
07 & -0.33 & $14.53 \%$ & $6.35 \%$ & $1.15 \%$ & $23.52 \%$ & $4.10 \%$ & $2.50 \%$ \\
08 & -0.40 & $18.28 \%$ & $7.59 \%$ & $6.05 \%$ & $25.61 \%$ & $2.20 \%$ & $6.09 \%$ \\
09 & -0.33 & $17.03 \%$ & $7.53 \%$ & $5.08 \%$ & $24.45 \%$ & $4.30 \%$ & $5.26 \%$ \\
10 & -0.38 & $18.50 \%$ & $8.19 \%$ & $5.10 \%$ & $27.11 \%$ & $4.58 \%$ & $5.92 \%$ \\
11 & -0.40 & $19.34 \%$ & $9.14 \%$ & $8.36 \%$ & $26.72 \%$ & $3.72 \%$ & $6.51 \%$ \\
12 & -0.45 & $15.84 \%$ & $12.13 \%$ & $5.63 \%$ & $27.27 \%$ & $4.74 \%$ & $4.61 \%$ \\
\hline Average & -0.29 & $12.25 \%$ & $5.56 \%$ & $3.76 \%$ & $17.92 \%$ & $4.42 \%$ & $4.76 \%$ \\
\hline
\end{tabular}

Source: Study data

TABLE 10 - Hedging effectiveness of Minimum-VaR (Kernel method) for grape

\begin{tabular}{cccccccc}
\hline \multirow{2}{*}{ Maturity } & $\mathrm{h}$ & \multicolumn{2}{c}{ Estimation sample (Jan/1989-Dec/2008) } & \multicolumn{2}{c}{ Validation sample (Jan/2009-Dec/2013) } \\
\cline { 3 - 8 } & & Variance reduction & VaR reduction & CVaR reduction & Variance reduction & VaR reduction & CVaR reduction \\
\hline 01 & 0.23 & $0.04 \%$ & $2.18 \%$ & $0.04 \%$ & $-9.54 \%$ & $-9.24 \%$ & $-3.29 \%$ \\
02 & -0.35 & $13.97 \%$ & $3.45 \%$ & $3.49 \%$ & $23.75 \%$ & $6.96 \%$ & $10.27 \%$ \\
03 & -0.55 & $25.36 \%$ & $9.77 \%$ & $8.57 \%$ & $33.75 \%$ & $27.46 \%$ & $19.28 \%$ \\
04 & -0.67 & $21.61 \%$ & $10.34 \%$ & $5.31 \%$ & $34.84 \%$ & $23.86 \%$ & $24.80 \%$ \\
05 & -0.11 & $3.71 \%$ & $0.12 \%$ & $0.08 \%$ & $6.63 \%$ & $2.98 \%$ & $3.57 \%$ \\
06 & -0.38 & $12.58 \%$ & $4.61 \%$ & $1.23 \%$ & $17.62 \%$ & $8.40 \%$ & $7.82 \%$ \\
07 & -0.64 & $24.81 \%$ & $17.11 \%$ & $9.11 \%$ & $28.77 \%$ & $9.53 \%$ & $0.03 \%$ \\
08 & -0.52 & $19.12 \%$ & $11.05 \%$ & $5.41 \%$ & $27.24 \%$ & $6.98 \%$ & $5.04 \%$ \\
09 & -0.59 & $25.83 \%$ & $11.03 \%$ & $8.02 \%$ & $32.41 \%$ & $12.17 \%$ & $9.15 \%$ \\
10 & -0.43 & $18.08 \%$ & $6.80 \%$ & $5.12 \%$ & $20.48 \%$ & $9.81 \%$ & $10.76 \%$ \\
11 & -0.37 & $17.09 \%$ & $1.63 \%$ & $2.89 \%$ & $14.30 \%$ & $9.13 \%$ & $7.24 \%$ \\
12 & -0.20 & $12.10 \%$ & $1.27 \%$ & $4.37 \%$ & $6.17 \%$ & $10.32 \%$ & $6.63 \%$ \\
\hline Average & -0.38 & $16.19 \%$ & $6.61 \%$ & $4.47 \%$ & $19.70 \%$ & $9.86 \%$ & $8.44 \%$ \\
\hline
\end{tabular}

Source: Study data

Finally, Table 13 summarizes all the averages hedge ratios and indexes reductions calculated in this study: per sample (estimation or validation), per risk index (Variance, VaR or CVaR), per method (Minimum-Variance, Minimum $\mathrm{VaR}$ and $\mathrm{CVaR}$ by Historical Simulation and Minimum $\mathrm{VaR}$ and $\mathrm{CVaR}$ by Kernel function) and per fruit (mango or grape).
Based on these results, it is possible to conclude for this study, on average, that: (1) minimizing the variance implies a greater optimal hedge ratio (OHR) than minimizing the VaR/CVaR, regardless the approach that was chosen (Historical Simulation or Kernel function), but it does not imply diminishing the VaR/CVaR; (2) minimizing the VaR/ 
CVaR by the Kernel method implies a diminishing in the variance, regardless of the sample and the fruit that was chosen; and (3) minimizing the CVaR by the
Kernel method implies in the second best decrease of the variance, regardless of the sample and the fruit that was chosen.

TABLE 11 - Hedging effectiveness of Minimum-CVaR (Kernel method) for mango

\begin{tabular}{cccccccc}
\hline \multirow{2}{*}{ Maturity } & $\mathrm{h}$ & \multicolumn{2}{c}{ Estimation sample (Jan/1989-Dec/2008) } & \multicolumn{2}{c}{ Validation sample (Jan/2009-Dec/2013) } \\
\cline { 3 - 8 } & & Variance reduction & VaR reduction & CVaR reduction & Variance reduction & VaR reduction & CVaR reduction \\
\hline 01 & 0.23 & $0.03 \%$ & $1.92 \%$ & $1.05 \%$ & $-3.71 \%$ & $2.32 \%$ & $-0.42 \%$ \\
02 & 0.28 & $-5.14 \%$ & $-6.89 \%$ & $1.07 \%$ & $-11.97 \%$ & $-9.46 \%$ & $-6.78 \%$ \\
03 & -0.95 & $17.77 \%$ & $-1.93 \%$ & $7.83 \%$ & $23.34 \%$ & $9.97 \%$ & $9.10 \%$ \\
04 & -0.42 & $9.71 \%$ & $1.89 \%$ & $2.29 \%$ & $17.63 \%$ & $5.66 \%$ & $6.30 \%$ \\
05 & -0.72 & $25.75 \%$ & $-2.96 \%$ & $8.21 \%$ & $34.72 \%$ & $12.62 \%$ & $14.11 \%$ \\
06 & -0.37 & $16.77 \%$ & $0.77 \%$ & $4.26 \%$ & $21.30 \%$ & $5.29 \%$ & $9.72 \%$ \\
07 & -0.31 & $13.94 \%$ & $6.30 \%$ & $1.15 \%$ & $22.40 \%$ & $3.96 \%$ & $2.54 \%$ \\
08 & -0.50 & $20.43 \%$ & $6.78 \%$ & $6.41 \%$ & $28.98 \%$ & $1.18 \%$ & $6.02 \%$ \\
09 & -0.45 & $20.31 \%$ & $6.98 \%$ & $5.57 \%$ & $30.26 \%$ & $4.33 \%$ & $4.68 \%$ \\
10 & -0.43 & $19.83 \%$ & $7.88 \%$ & $5.21 \%$ & $29.38 \%$ & $4.38 \%$ & $5.53 \%$ \\
11 & -0.67 & $23.29 \%$ & $6.10 \%$ & $10.21 \%$ & $33.97 \%$ & $-4.83 \%$ & $-3.71 \%$ \\
12 & -0.60 & $18.01 \%$ & $9.67 \%$ & $6.17 \%$ & $32.49 \%$ & $3.78 \%$ & $3.56 \%$ \\
\hline Average & -0.41 & $15.06 \%$ & $3.04 \%$ & $4.95 \%$ & $21.57 \%$ & $3.27 \%$ & $4.22 \%$ \\
\hline
\end{tabular}

Source: Study data

TABLE 12 - Hedging effectiveness of Minimum-CVaR (Kernel method) for grape

\begin{tabular}{cccccccc}
\hline \multirow{2}{*}{ Maturity } & $\mathrm{h}$ & \multicolumn{2}{c}{ Estimation sample (Jan/1989-Dec/2008) } & \multicolumn{2}{c}{ Validation sample (Jan/2009-Dec/2013) } \\
\cline { 3 - 8 } & & $\begin{array}{c}\text { Variance } \\
\text { reduction }\end{array}$ & $\begin{array}{c}\text { VaR } \\
\text { reduction }\end{array}$ & $\begin{array}{c}\text { CVaR } \\
\text { reduction }\end{array}$ & $\begin{array}{c}\text { Variance } \\
\text { reduction }\end{array}$ & $\begin{array}{c}\text { VaR } \\
\text { reduction }\end{array}$ & $\begin{array}{c}\text { CVaR } \\
\text { reduction }\end{array}$ \\
\hline 01 & 0.12 & $0.51 \%$ & $1.61 \%$ & $0.45 \%$ & $-4.31 \%$ & $-4.16 \%$ & $-1.49 \%$ \\
02 & -0.30 & $12.55 \%$ & $3.38 \%$ & $3.59 \%$ & $21.20 \%$ & $5.52 \%$ & $9.06 \%$ \\
03 & -0.86 & $29.97 \%$ & $7.00 \%$ & $9.57 \%$ & $39.96 \%$ & $35.74 \%$ & $24.69 \%$ \\
04 & -0.87 & $22.52 \%$ & $9.93 \%$ & $5.60 \%$ & $37.09 \%$ & $24.97 \%$ & $26.62 \%$ \\
05 & -0.10 & $3.40 \%$ & $0.12 \%$ & $0.08 \%$ & $6.06 \%$ & $2.73 \%$ & $3.27 \%$ \\
06 & -0.25 & $9.41 \%$ & $3.95 \%$ & $1.53 \%$ & $12.68 \%$ & $6.06 \%$ & $5.96 \%$ \\
07 & -0.63 & $24.67 \%$ & $17.11 \%$ & $9.11 \%$ & $28.61 \%$ & $9.54 \%$ & $0.33 \%$ \\
08 & -0.54 & $19.44 \%$ & $11.03 \%$ & $5.42 \%$ & $27.80 \%$ & $6.87 \%$ & $4.93 \%$ \\
09 & -0.59 & $25.83 \%$ & $11.03 \%$ & $8.02 \%$ & $32.41 \%$ & $12.17 \%$ & $9.15 \%$ \\
10 & -0.86 & $22.35 \%$ & $0.98 \%$ & $6.64 \%$ & $24.30 \%$ & $4.19 \%$ & $4.82 \%$ \\
11 & -0.33 & $15.78 \%$ & $1.55 \%$ & $2.92 \%$ & $13.35 \%$ & $8.45 \%$ & $6.79 \%$ \\
12 & -0.30 & $15.98 \%$ & $0.03 \%$ & $5.26 \%$ & $6.70 \%$ & $13.74 \%$ & $8.86 \%$ \\
\hline Average & -0.46 & $16.87 \%$ & $5.64 \%$ & $4.85 \%$ & $20.49 \%$ & $10.49 \%$ & $8.58 \%$ \\
\hline
\end{tabular}

Source: Study data 
TABLE 13 - Summary results for price risk management via different hedging approaches

\begin{tabular}{|c|c|c|c|c|c|c|c|c|}
\hline \multirow{2}{*}{ Fruit } & \multirow{2}{*}{ Method } & \multirow{2}{*}{$\begin{array}{l}\text { Average } \\
\text { OHR }\end{array}$} & \multicolumn{3}{|c|}{$\begin{array}{c}\text { Estimation sample } \\
\text { (Jan/1989-Dec/2008) }\end{array}$} & \multicolumn{3}{|c|}{$\begin{array}{c}\text { Validation sample } \\
\text { (Jan/2009-Dec/2013) }\end{array}$} \\
\hline & & & $\begin{array}{l}\text { Variance } \\
\text { reduction }\end{array}$ & $\begin{array}{l}\text { VaR } \\
\text { reduction }\end{array}$ & $\begin{array}{c}\text { CVaR } \\
\text { reduction }\end{array}$ & $\begin{array}{l}\text { Variance } \\
\text { reduction }\end{array}$ & $\begin{array}{l}\mathrm{VaR} \\
\text { reduction }\end{array}$ & $\begin{array}{l}\text { CVaR } \\
\text { reduction }\end{array}$ \\
\hline \multirow{5}{*}{$\underset{0}{3}$} & Min variance & -0.63 & $17.44 \%$ & $-6.08 \%$ & $2.53 \%$ & $27.45 \%$ & $-1.26 \%$ & $-0.76 \%$ \\
\hline & Min Var HS & -0.27 & $10.33 \%$ & $8.26 \%$ & $2.86 \%$ & $15.25 \%$ & $-2.05 \%$ & $1.97 \%$ \\
\hline & Min VaR Kernel & -0.29 & $12.25 \%$ & $5.56 \%$ & $3.76 \%$ & $17.92 \%$ & $4.42 \%$ & $4.76 \%$ \\
\hline & Min CVaR HS & -0.38 & $14.21 \%$ & $0.90 \%$ & $4.53 \%$ & $20.27 \%$ & $-0.97 \%$ & $-0.13 \%$ \\
\hline & Min CVaR Kernel & -0.41 & $15.06 \%$ & $3.04 \%$ & $4.95 \%$ & $21.57 \%$ & $3.27 \%$ & $4.22 \%$ \\
\hline \multirow{5}{*}{$\stackrel{9}{\frac{0}{0}}$} & Min variance & -0.67 & $19.96 \%$ & $0.31 \%$ & $2.69 \%$ & $25.01 \%$ & $14.88 \%$ & $4.49 \%$ \\
\hline & Min Var HS & -0.20 & $6.69 \%$ & $11.10 \%$ & $2.64 \%$ & $9.29 \%$ & $4.39 \%$ & $-3.00 \%$ \\
\hline & Min VaR Kernel & -0.38 & $16.19 \%$ & $6.61 \%$ & $4.47 \%$ & $19.70 \%$ & $9.86 \%$ & $8.44 \%$ \\
\hline & Min CVaR HS & -0.41 & $16.12 \%$ & $3.33 \%$ & $4.99 \%$ & $19.03 \%$ & $11.19 \%$ & $4.50 \%$ \\
\hline & Min CVaR Kernel & -0.46 & $16.87 \%$ & $5.64 \%$ & $4.85 \%$ & $20.49 \%$ & $10.49 \%$ & $8.58 \%$ \\
\hline
\end{tabular}

Source: Study data

\section{CONCLUSION}

This study identified the hedge effectiveness of futures contracts for the Brazilian exported mango and grape by $\mathrm{VaR} / \mathrm{CVaR}$ hedging approaches, in comparison to an unhedged strategy $(\mathrm{OHR}=0)$, given that they have not any hedging tool to mitigate their price risk.

Besides, it contributes to broadening the discussion about measures of risk and hedging performance of portfolios, mainly for the agricultural issues.

In relation to the first specific objective, it was noticed that a variance reduction does not imply in VaR/ CVaR reduction, and when it occurs, it does not happen of the same way. The results show that the VaR/CVaR can increase when using Minimum-Variance approach, due to it can potentially augment the left-skewness and kurtosis, making its effect on the portfolio risk uncertain, as already demonstrated in a previous study (HARRIS; SHEN, 2006).

Regarding the second specific objective, in general, the Minimum-CVaR via the Kernel method does improve the reduction in portfolio's VaR and variance instead of the Minimum-Variance approach, with a smaller optimal hedge ratio. However, these reductions were not as larger as have seen in the previous studies that employed static hedging approaches (HARRIS; SHEN, 2006; CAO; HARRIS; SHEN, 2010; COTTER; HANLY, 2006). This fact can be attributed to the existence of heteroscedasticity in these time series, which may compromise the effectiveness of static hedging approaches.

On the other hand, because of the lower optimal found hedge rations, the agents involved could be encouraged to carry out such hypothetical operations, due to the prospect of low brokerage costs. In addition, it is important to mention that all the hedge strategies adopted in this study assumed that all agents have maximum aversion to risk.

Therefore, the answer to the main objective of this paper is presented by Minimum-CVaR Kernel because it is the coherent risk measure with the best results.

For mango, the average hedge effectiveness of variance, $\mathrm{VaR}$, and $\mathrm{CVaR}$ were, respectively, $15.06 \%$, $3.04 \%$, and $4.95 \%$ in the estimation sample and $21.57 \%$, $3.27 \%$, and $4.22 \%$ in the validation sample. Individually, the contract with maturity at five months, in a short position, had the largest $\mathrm{CVaR}$ reduction in the validation sample.

For grape, the average hedge effectiveness of variance, $\mathrm{VaR}$, and $\mathrm{CVaR}$ were, respectively, $16.87 \%$, $5.64 \%$, and $4.85 \%$ in the estimation sample and $20.49 \%$, $10.49 \%$, and $8.58 \%$ in the validation sample. Individually, the contract with maturity at four months, also in a short position, had the largest $C V a R$ reduction in the validation sample.

Additionally, it was seen that the hedge ratio, via Minimum-VaR/CVaR, does not tend to naive hedge as 
the maturity increases, following the same results in the previous studies for the variance (OLIVEIRA; SANTOS, 2015, 2017).

For future investigations, it is suggested some paths to get better the results achieved in this study. The first concerns new ways of simulating futures prices, with the aim of increasing the accuracy in obtaining these values and augment their correlation with spot prices. The second relates to using heteroscedastic models to improve the hedge effectiveness (especially the multivariate GARCH models), once it is present in these time series, even though there are no structural breaks in them. Besides, it was also observed a change of the hedge ratios between the samples, which the cause can be attributed to the conditional changes in the moments [variance, skewness, and kurtosis] of the series. The third is to use a risk/return index, like a Sharpe ratio, to measure other cases than the maximum aversion to risk.

Thus, a theoretical and methodological framework would be constructed to analyze the price risk in Brazilian exporting fruit production, with a view to a practical implementation among its stakeholders.

\section{REFERENCES}

ACERBI, C.; TASCHE, D. On the coherence of expected shortfall. Journal of Banking \& Finance, v.26, n.7, p.1487-1503, Jul. 2002. DOI: https://doi.org/10.1016/ S0378-4266(02)00283-2.

ARTZNER, P.; DELBAEN, F.; EBER, J. M.; HEATH, D. Coherent measures of risk. Mathematical Finance, v.9, n.3, p.203-228, Jul. 1999. DOI: https://doi.org/10.1111/14679965.00068 .

BERA, A. K.; HIGGINS, M. L. ARCH models: properties, estimation and testing. Journal of Economic Surveys, v. 7, n. 4, p. 305-366, Dec. 1993. DOI: https://doi. org/10.1111/j.1467-6419.1993.tb00170.x.

BLIEMEL, F. Theil's forecast accuracy coefficient: a clarification. Journal of Marketing Research, Chicago, v.10, p.444-446, 1973. DOI: http://dx.doi. org/10.2307/3149394.

BRASIL. Ministério do Planejamento, Orçamento e Gestão. Instituto Brasileiro de Geografia e Estatística. Produção Agrícola Municipal: culturas temporárias e permanentes, Rio de Janeiro, v.43, p.1-62, 2016.
BRASIL. Ministério do Desenvolvimento, Indústria e Comércio Exterior. Comex Stat. 2014a. Available in: http://comexstat.mdic.gov.br/pt/home. Access: $31 / 01 / 2014$.

BRASIL. Ministério do Planejamento, Orçamento e Gestão. Instituto Brasileiro de Geografia e Estatística. Produto Interno Bruto dos Municípios 2010. Contas Nacionais, n. 39. Rio de Janeiro: IBGE, 2012.

BRASIL. Ministério do Planejamento, Orçamento e Gestão. Instituto Brasileiro de Geografia e Estatística. Produto Interno Bruto dos Municípios 2012. Contas Nacionais, n. 43. Rio de Janeiro: IBGE, 2014b.

BRESSAN, A. A. Tomada de decisão em futuros agropecuários com modelos de previsão de séries temporais. RAE eletrônica, São Paulo, v. 3, n. 1, Art. 9, Jan/Jun 2004. DOI: http://dx.doi.org/10.1590/S167656482004000100005 .

BREUSCH, T. S. Testing for autocorrelation in dynamic linear models. Australian Economic Papers, v. 17, n. 31, p. 334-355, Dec. 1978. DOI: https://doi. org/10.1111/j.1467-8454.1978.tb00635.x.

BROOKS, C.; HENRY, O. T.; PERSAND, G. The effects of asymmetries on optimal hedge ratios. Journal of Business, v.75, n.2, p.333-352, Apr. 2002. DOI: http:// dx.doi.org/10.1086/338484.

BUENO, G.; BACCARIN, J. G. Participação das principais frutas brasileiras no comércio internacional: 1997 a 2008.

Revista Brasileira de Fruticultura, Jaboticabal, v.34, n.2, p.424-434, Jun, 2012. DOI: http://dx.doi.org/10.1590/ S0100-29452012000200015.

CAO, Z.; HARRIS, R. D. F.; SHEN, J. Hedging and Value at Risk: a semi-parametric approach. The Journal of Futures Markets, v.30, n.8, p.780-794, Aug. 2010. DOI: https://doi.org/10.1002/fut.20440.

CAPITANI, D. H. D.; MATTOS, F. L. Feasibility of new agricultural futures contract: a study in the Brazilian rice market. Proceedings of the AAEA and WAEA Annual Meeting, San Francisco, CA, 2015. Available: http:// ageconsearch.umn.edu/record/205565/files/ AAEA\%20 2015_Capitani_Mattos-1.pdf. 
. Measurement of commodity price risk: an overview of Brazilian agricultural markets. Revista de Economia e Sociologia Rural, Piracicaba, v.55, n.3, p.515-532, Jul./set., 2017. DOI: http://dx.doi. org/10.1590/1234-56781806-94790550306.

CASELLA, G.; BERGER, R. L. Statistical Inference. 2. ed. Pacific Grove: Duxbury-Thomson Learning, 2002.

CASTRO, M. C.; SILVA NETO, W. A. Risco na variação de preços agropecuários: evidências empíricas para os mercados de soja, milho e boi gordo em Rio Verde, Goiás. Revista Econômica do Nordeste, Fortaleza, v.49, n.1, p.8397, jan./mar., 2018. Available in: https://www.bnb.gov.br/ projwebren/Exec/artigoRenPDF.aspx?cd_artigo_ren=1737.

CHANG, K. L. The optimal value-at-risk hedging strategy under bivariate regime switching ARCH framework. Applied Economics, v.43, n.21, p.2627-2640, 2011. DOI: http://dx.doi.org/10.1080/00036840903299771.

CHEN, S. S.; LEE, C. F.; SHRESTHA, K. Futures hedge ratio: a review. The quarterly review of economics and finance, v.43, n.3, p.433-465, autumn, 2003. DOI: http:// dx.doi.org/10.1016/S1062-9769(02)00191-6.

. An empirical analysis of the relationship between the hedge ratio and hedging horizon: a simultaneous estimation of the short and long run hedge ratios. The Journal of Futures Markets, v.24, n.4, p.359-386, Feb. 2004. DOI: http://dx.doi.org/10.1002/fut.10121.

COTTER, J.; HANLY, J. Reevaluating hedging performance. The Journal of Futures Markets, v.26, n.7, p. 369-390, 2006. DOI: http://dx.doi.org/10.1002/ fut.20212.

Hedging effectiveness under conditions of asymmetry. The European Journal of Finance, v.18, n.2, p.135-147, 2012. DOI: https://doi.org/10.1080/1351 847X.2011.574977.

EDERINGTON, L. H. The hedging performance of the new futures markets. The Journal of Finance, v. 34, n. 1, p. 157-170, Mar. 1979. DOI: http://dx.doi. org/10.1111/j.1540-6261.1979.tb02077.x .

ELTON, E. J.; GRUBER, M. J.; BROWN, S. J.; GOETZMANN, W. N. Moderna teoria de carteiras e análise de investimentos. São Paulo: Atlas, 2004.
ENGLE, R. F. Autoregressive conditional heteroscedasticity with estimates of the variance of United Kingdom inflation. Econometrica, v.50, n.4, p.987-1007, Jul 1982. Available in: http://www.jstor.org/stable/1912773.

FELIPE, I. J. S.; FRAILE, G. B. Perda máxima aceitável para investimento de risco em commodity brasileira. REGE - Revista de Gestão, São Paulo, v.24, n.3, p.224-234, jul./set., 2017. DOI: https://doi.org/10.1016/j. rege.2017.05.002.

FERREIRA, M. O.; SAMPAIO, Y. S. B. Estudos para a implantação de mercados futuros de manga e uva no Brasil como solução para alavancar as exportações de frutas topicais. Revista Desenbahia, Salvador, n.11, p. 67-98, set. 2009. Available: http:// www.desenbahia.ba.gov.br/publitao/arquivos/arquivos/ ae68edab3bca43369e4e87a527878799.pdf .

GODFREY, L. G. Testing against general autoregressive and moving average error models when the regressors include lagged dependent variables. Econometrica, v. 46, n. 6, p. 1293-1301, Nov. 1978. DOI: http://dx.doi. org/10.2307/1913829.

GOURIEROUX, C.; LAURENT, J. P.; SCAILlET, O. Sensitivity analysis of Values at Risk. Journal of Empirical Finance, v.7, n.3-4, p.225-245, Nov. 2000. DOI: http://dx.doi.org/10.1016/S0927-5398(00)00011-6.

HARRIS, R. D. F.; SHEN, J. Hedging and Value at Risk. The Journal of Futures Markets, v.26, n.4, p. 369-390, 2006. DOI: http://dx.doi.org/10.1002/fut.20195.

HARRIS, R. D. F.; SHEN, J.; STOJA, E. The limits to minimum-variance hedging. Journal of Business Finance \& Accounting, v.37, n.5-6, p.737-761, Jul. 2010. DOI: https://doi.org/10.1111/j.1468-5957.2009.02170.x.

HULL, J. C. Options, Futures and other derivatives. 8. ed. Boston: Pearson Prentice Hall, 2012.

JOHNSON, L. L. The theory of hedging and speculation in commodity futures. The Review of Economic Studies, v. 27, n. 3, p. 139-151, Jun. 1960. Available in: http://www. jstor.org/stable/2296076 .

JORION, P. Value-at-Risk: the new benchmarking for managing financial risk. 3. ed. New York: McGraw-Hill, 2007. 
JULiÃO, C. C. B.; BRANCO, D. K. S.; LIMA, J. E. Exportação de uva no Vale do São Francisco: uma análise a partir de vetores autorregressivos. Revista Econômica do Nordeste, Fortaleza, v.48, n.2, p.75-83, abr./jun., 2017. Available in: https://www.bnb.gov.br/projwebren/Exec/ artigoRenPDF.aspx?cd_artigo_ren $=1705$.

KWIATKOWSKI, D.; PHILLIPS, P. C. B.; SCHMIDT, P. SHIN, Y. (KPSS). Testing the null hypothesis of stationarity against the alternative of a unit root. Journal of Econometrics, v.54, n.1-3, p.159-178, Oct-Dec, 1992. DOI: https://doi.org/10.1016/03044076(92)90104-Y.

LIEN, D.; TSE, Y. K. Some recent developments in futures hedging. Journal of Economic Surveys, v.16, n.3, p.357-396, 2002. DOI: https://doi.org/10.1111/14676419.00172 .

LIMA, J. R. F.; SILVA, J. S.; SANTOS, R. K. B. Comportamento dos preços da manga exportada do Brasil: 2004-2012. Organizações Rurais \& Agroindustriais, Lavras, v. 15, n. 3, p. 370-380, 2013. Available in: http:// www.spell.org.br/documentos/download/21694.

LJUNG, G. M.; BOX, G. E. P. On a measure of lack of fit in time series models. Biometrika, v. 65, n. 2, p. 297-303, Aug. 1978. DOI: http://dx.doi. org/10.2307/2335207.

MANDL, C.; BARROS, B. PE: crise mundial atinge produção de frutas no Vale do São Francisco. Valor Econômico, 16/01/2009. Disponível em: <http://www. paginarural.com.br/noticia/104189/crise-mundial-atingeproducao-de-frutas-no-vale-do-sao-francisco $>$. Acesso: 05/05/2011.

MANFREDO, M. R.; LEUTHOLD, R. M. Agricultural Applications of Value-at-Risk Analysis: A Perspective. Proceedings of the NCR-134Conference on Applied Commodity Price Analysis, Forecasting, and Market Risk Management. Chicago, IL, 1998. Available in: http://econwpa.repec.org/eps/fin/papers/9805/9805002. pdf.

MOREIRA, V. R.; SOUZA, A.; DUCLÓS, L. C. Avaliação de retornos e riscos na comercialização de milho: estudo de caso usando o Value-at-Risk. Revista de Economia e Sociologia Rural, Piracicaba, v.52, n.2, p.303-322, abr./jun., 2014. DOI: http://dx.doi.org/10.1590/S010320032014000200006.

MYERS, R. J.; THOMPSON, S. R. Generalized optimal hedge ratio estimation. American Journal of Agricultural Economics, v.71, n.4, p.858-868, Nov. 1989. DOI: https:// doi.org/ 10.2307/1242663.

NADARAJAH, S.; CHAN, S.; AFUECHETA, E. Tabulations for value at risk and expected shortfall. Communications in Statistics-Theory and Methods, v.46, n.12, p.5596-5984, 2017. DOI: https://doi.org/10.1 080/03610926.2015.1116572.

OLIVEIRA, A. M. B.; ARAÚJO, A. M. Investigação sobre persistência na variância e quebras estruturais nas séries de preços da manga e uva exportadas da Bahia. Exacta Engenharia de Produção, São Paulo, v.16, n.1, p.33-42, 2018. DOI: https://doi.org/10.5585/exactaep.v16n1.6899.

OLIVEIRA, A. M. B.; SANTOS, J. F. Previsões de razões ótimas de hedge para a manga exportada brasileira. Nova Economia, Belo Horizonte, v.27, n.3, p.671-703, 2017. DOI: http://dx.doi.org/10.1590/0103-6351/3288.

Simulações de razões ótimas de hedge para a uva exportada brasileira. Organizações Rurais \& Agroindustriais, Lavras, v.17, n.1, p.101-118, 2015. Available in: http://www.spell.org.br/documentos/ download/35235.

PFLUG, G. C. Some Remarks on the Value-at-Risk and the Conditional Value-at-Risk. In: URYASEV S.P. (eds) Probabilistic Constrained Optimization. Nonconvex Optimization and its Applications, v.49. Boston: Springer, 2000. DOI: https://doi.org/10.1007/978-1-4757-31507_15.

SAM, A. G. Nonparametric estimation of market risk: an application to agricultural commodity futures. Agricultural Finance Review, v.70, n.2, p.285-297, 2010. DOI: http://dx.doi.org/10.1108/00021461011065292.

SOUZA, W. A. R.; MARTINES-FILHO, J. G.; ZANCAN, C.; COSTA, A. C. S.; QUEIRÓZ, A. G. A. Análise do potencial econômico para mercados futuros de arroz do Mercosul. Sociedade, Contabilidade e Gestão, Rio de Janeiro, v.10, n.2, p.70-87, mai/ago, 2015. Available: http://www.spell.org.br/documentos/ download/38159. 
SPANOS, A. Probability theory and statistical inference: econometric modelling with observational data. New York: Cambridge University Press, 1999.

SCHWARZ, G. Estimating the dimension of a model. The Annals of Statistics, v. 6, n. 2, p. 461-464, Mar. 1978. Available in: https://www.jstor.org/stable/2958889.
WANG, C.; ZHAO, J.; HUANG, M. Measurement of the fluctuation risk of the China Fruit Market Price based on VaR. International Conference on Agricultural Risk and Food Security. Agriculture and Agricultural Science Procedia, Beijing, v.1, p.212-218, 2010. DOI: http://dx.doi.org/10.1016/j. aaspro.2010.09.026.

Organizações Rurais \& Agroindustriais, Lavras, v. 20, n. 2, p. 134-154, 2018 


\section{APPENDIX A}

TABLE 14 - Forecasting equations coefficients, in ARIMA reduced format, for simulated futures prices

\begin{tabular}{|c|c|c|}
\hline Maturity & Mango & Grape \\
\hline 01 & MA(1) MA(2) ARCH(1) & $\mathrm{AR}(1) \mathrm{AR}(2) \mathrm{AR}(3) \mathrm{MA}(1) \mathrm{MA}(2) \mathrm{MA}(3)$ \\
\hline 02 & $\mathrm{AR}(1) \mathrm{MA}(1) \mathrm{MA}(2) \mathrm{ARCH}(1)$ & $\mathrm{AR}(1) \mathrm{AR}(2) \mathrm{MA}(1) \mathrm{MA}(2) \mathrm{MA}(3) \mathrm{MA}(4) \mathrm{MA}(5)$ \\
\hline 03 & MA(1) MA(2) MA(3) MA(4) GARCH(1,1) & $\operatorname{AR}(1) \operatorname{AR}(3) \operatorname{AR}(8) \mathrm{MA}(1) \mathrm{MA}(2) \mathrm{MA}(3)$ \\
\hline 04 & MA(1) MA(2) MA(3) MA(4) MA(5) GARCH(1,1) & $\mathrm{AR}(6) \mathrm{AR}(8) \mathrm{MA}(1) \mathrm{MA}(2) \mathrm{MA}(3) \mathrm{MA}(4) \mathrm{MA}(5) \mathrm{MA}(6)$ \\
\hline 05 & $\operatorname{AR}(1) \operatorname{AR}(2) \mathrm{MA}(1) \mathrm{MA}(2) \mathrm{MA}(3) \mathrm{MA}(4) \mathrm{MA}(5)$ & MA(1) MA(2) MA(3) MA(4) MA(5) MA(6) \\
\hline 06 & $\operatorname{AR}(1) \operatorname{SAR}(6) \mathrm{MA}(1) \mathrm{MA}(2) \mathrm{SMA}(12) \operatorname{IGARCH}(1,1)$ & $\operatorname{AR}(1) \operatorname{AR}(2) \operatorname{AR}(7) \mathrm{MA}(3) \mathrm{MA}(6)$ \\
\hline 07 & $\operatorname{AR}(1) \operatorname{AR}(5) \mathrm{MA}(7) \operatorname{IGARCH}(1,1)$ & MA(1) MA(2) MA(3) MA(4) MA(5) MA(6) MA(7) MA(8) MA(9) \\
\hline 08 & AR(1) MA(5) MA(8) TGARCH(1,1) & $\operatorname{AR}(1) \operatorname{AR}(6) \mathrm{MA}(8)$ \\
\hline 09 & $\operatorname{AR}(1) \operatorname{AR}(5) \mathrm{MA}(9) \mathrm{TGARCH}(1,1)$ & $\operatorname{AR}(1) \operatorname{AR}(5) \operatorname{MA}(9)$ \\
\hline 10 & $\operatorname{AR}(1) \operatorname{AR}(5) \operatorname{MA}(10) \operatorname{IGARCH}(1,1)$ & $\operatorname{AR}(1) \operatorname{AR}(6) \mathrm{MA}(10)$ \\
\hline 11 & $\operatorname{AR}(1) \operatorname{AR}(5) \mathrm{MA}(11) \operatorname{IGARCH}(1,1)$ & $\operatorname{AR}(1) \operatorname{AR}(6) \mathrm{MA}(11)$ \\
\hline 12 & $\operatorname{AR}(2) \mathrm{MA}(1) \mathrm{MA}(2) \mathrm{MA}(3) \mathrm{SMA}(12) \operatorname{IGARCH}(1,1)$ & $\mathrm{AR}(1) \mathrm{AR}(3) \mathrm{MA}(3) \mathrm{MA}(12)$ \\
\hline
\end{tabular}

Note: All coefficients are significative from $10 \%$ of confidence. The prediction error is up to $23 \%$ for mango, and $16 \%$ for the grape. Source: Oliveira and Santos $(2015,2017)$

TABLE 15 - Diagnostic of the forecasting equations for the log returns of exported mango and grape This table shows the forecasting equation's diagnosis per month, per explanation capacity (adjusted $\mathrm{R}^{2}$ ), per parsimony $(B I C)$, per serial correlation (B-G), per heteroskedasticity (L-B Q) and prediction quality $\left(\mathrm{U}_{1}\right)$, for estimation and validation samples, for exported mango and grape.

\begin{tabular}{|c|c|c|c|c|c|c|c|c|c|c|}
\hline \multirow{3}{*}{$\begin{array}{c}\text { Time } \\
\text { (month) }\end{array}$} & \multicolumn{5}{|c|}{ Mango } & \multicolumn{5}{|c|}{ Grape } \\
\hline & \multicolumn{4}{|c|}{ (Jan-1989 to Dec-2008) } & \multirow{2}{*}{$\begin{array}{c}U_{1} \\
(1989- \\
2013)\end{array}$} & \multicolumn{4}{|c|}{ (Jan-1989 to Dec-2008) } & \multirow{2}{*}{$\begin{array}{c}U_{1} \\
(1989 \\
2013)\end{array}$} \\
\hline & $\mathrm{R}^{2}$ ad. & BIC & B-G & L-B Q & & $\mathrm{R}^{2}$ ad. & $\mathrm{BIC}$ & B-G & L-B Q & \\
\hline 01 & 0.176 & -0.225 & $0.154^{\circ}$ & $0.843^{\infty}$ & 0.140 & 0.246 & -0.384 & 0.884 & 0.614 & 0.106 \\
\hline 02 & 0.517 & -0.206 & $0.279^{\circ}$ & $0.995^{\circ 0}$ & 0.144 & 0.519 & -0.344 & 0.519 & 0.337 & 0.107 \\
\hline 03 & 0.586 & -0.154 & $0.407^{\circ}$ & $0.999^{\circ}$ & 0.137 & 0.633 & -0.376 & 0.497 & 0.745 & 0.107 \\
\hline 04 & 0.598 & -0.134 & $0.347^{\circ}$ & $0.999^{\circ}$ & 0.138 & 0.596 & -0.284 & 0.115 & 0.523 & 0.109 \\
\hline 05 & 0.575 & -0.055 & 0.333 & 0.046 & 0.134 & 0.544 & -0.325 & 0.383 & 0.328 & 0.115 \\
\hline 06 & 0.593 & -0.547 & $0.075^{\circ}$ & $0.364^{\circ}$ & 0.136 & 0.541 & -0.357 & 0.494 & 0.520 & 0.112 \\
\hline 07 & 0.596 & -0.393 & $0.113^{\circ}$ & $0.984^{\circ \circ}$ & 0.138 & 0.556 & -0.248 & 0.923 & $0.953^{*}$ & 0.116 \\
\hline 08 & 0.549 & -0.260 & $0.359^{\circ}$ & $0.362^{\circ}$ & 0.139 & 0.624 & -0.298 & 0.207 & 0.692 & 0.118 \\
\hline 09 & 0.587 & -0.376 & $0.270^{\circ}$ & $0.201^{\circ \mathrm{o}}$ & 0.144 & 0.640 & -0.329 & 0.017 & 0.918 & 0.118 \\
\hline 10 & 0.598 & -0.449 & $0.293^{\circ}$ & $0757^{\circ}$ & 0.143 & 0.596 & -0.293 & 0.188 & 0.769 & 0.123 \\
\hline 11 & 0.583 & -0.450 & $0.210^{\circ}$ & $0.565^{\circ}$ & 0.141 & 0.524 & -0.313 & 0.059 & 0.365 & 0.122 \\
\hline 12 & 0.552 & -0.504 & $0.038^{\circ}$ & $0.772^{\circ}$ & 0.142 & 0.486 & -0.297 & 0.073 & 0.205 & 0.114 \\
\hline
\end{tabular}

* Values of the Engle (1982, p.999-1000) LM statistic test, with 10 lags, when L-B Q $<5 \%$, to resolve any doubts about heteroskedasticity in the variance. ${ }^{\circ} \mathrm{L}-\mathrm{B}$ Q Serial correlation results after heteroskedasticity correction. ${ }^{\text {oo }}$ Engle LM statistic test after heteroskedasticity correction

Source: Oliveira and Santos $(2015,2017)$ 
